\title{
Absorbing the Concept of Absorptive Capacity How to Realize Its Potential in the Organization Field
}

Volberda, Henk; Foss, Nicolai Juul; Lyles, Marjorie A.

Document Version

Final published version

Publication date:

2009

\section{License \\ CC BY-NC-ND}

Citation for published version (APA):

Volberda, H., Foss, N. J., \& Lyles, M. A. (2009). Absorbing the Concept of Absorptive Capacity: How to Realize Its Potential in the Organization Field. Center for Strategic Management and Globalization. SMG Working Paper No. $10 / 2009$

Link to publication in CBS Research Portal

\section{General rights}

Copyright and moral rights for the publications made accessible in the public portal are retained by the authors and/or other copyright owners and it is a condition of accessing publications that users recognise and abide by the legal requirements associated with these rights.

Take down policy

If you believe that this document breaches copyright please contact us (research.lib@cbs.dk) providing details, and we will remove access to the work immediately and investigate your claim. 
Absorbing the Concept of Absorptive Capacity: How To Realize Its Potential in the Organization Field

Henk W. Volberda

Nicolai J. Foss

Marjorie A. Lyles

SMG WP 10/2009

November 25, 2009 
SMG Working Paper No. 10/2009

November 25, 2009

ISBN: 978-87-91815-51-5

Center for Strategic Management and Globalization Copenhagen Business School

Porcelænshaven 24

2000 Frederiksberg

Denmark

www.cbs.dk/smg 


\title{
Absorbing the Concept of Absorptive Capacity: How To Realize Its Potential in the Organization Field
}

\author{
Henk W. Volberda
}

Department of Strategic Management \& Business Environment RSM Erasmus University

\&

INSCOPE: Research for Innovation

P.O.box 1738

3000 DR Rotterdam, The Netherlands

hvolberda@rsm.nl

Nicolai J Foss

Center for Strategic Management and Globalization

Copenhagen Business School

Porcelainshaven 24

2000 Frederiksberg, Denmark

njf.smg@cbs.dk

Department of Strategy and Management

Norwegian School of Economics and Business Administration

Breiviksveien 40; N-5045; Bergen; Norway

\section{Marjorie A. Lyles}

OneAmerica Chaired Professor of Business Administration

Professor of International Strategic Management

Indiana University, Kelley School of Business

801 West Michigan St., Indianapolis, Indiana 46202, USA

mlyles@iupui.edu

Invited Perspective Paper, Organization Science

\section{Acknowledgments:}

We are grateful to Linda Argote for her support throughout the process of writing this paper. We also want to thank Bas Warmerhoven for his assistance, Ed Noyons for his support in the bibliometric analysis, and to Kirsten Foss for comments on an earlier version of this paper. 


\title{
Absorbing the Concept of Absorptive Capacity: How to Realize Its Potential in the Organization Field
}

\begin{abstract}
The purpose of this Perspective Paper is to advance understanding of absorptive capacity, its underlying dimensions, its multi-level antecedents, its impact on firm performance and the contextual factors that affect absorptive capacity. Nineteen years after the Cohen and Levinthal 1990 paper, the field is characterized by a wide array of theoretical perspectives and a wealth of empirical evidence. In this paper, we first review these underlying theories and empirical studies of absorptive capacity. Given the size and diversity of the absorptive capacity literature, we subsequently map the existing terrain of research through a bibliometric analysis. The resulting bibliometric cartography shows the major discrepancies in the organization field, namely that (1) most attention so far has been focused on the tangible outcomes of absorptive capacity; (2) organizational design and individual level antecedents have been relatively neglected in the absorptive capacity literature; and (3) the emergence of absorptive capacity from the actions and interactions of individual, organizational and inter-organizational antecedents remains unclear. Building on the bibliometric analysis, we develop an integrative model that identifies the multi-level antecedents, process dimensions, and outcomes of absorptive capacity as well as the contextual factors that affect absorptive capacity. We argue that realizing the potential of the absorptive capacity concept requires more research that shows how "micro antecedents" and "macroantecedents" influence future outcomes such as competitive advantage, innovation, and firm performance. In particular, we identify conceptual gaps that may guide future research to fully exploit the absorptive capacity concept in the organization field and to explore future fruitful extensions of the concept.
\end{abstract}

Keywords: Absorptive capacity, knowledge management, organizational capabilities, multiple analytical levels, micro-foundations of absorptive capacity. 


\section{Introduction}

During the last two decades it has become almost axiomatic that knowledge lies at the core of the creation and maintenance of competitive advantage (McEvily and Chakravarthy, 2002; Grant, 1996a). In particular, the ability to innovate has become increasingly central as studies have revealed that innovative firms tend to demonstrate higher profitability, greater market value, superior credit ratings, and higher survival probabilities (Geroski, Machin and van Reenen 1993; Hall, 2000; Czarnitzki and Kraft 2004). Firms increasingly build innovation capacity by tapping into external knowledge sources (Chesbrough, 2003; Laursen and Salter, 2006). At the same time, it is widely accepted that critical knowledge is not always easily available through external sources (Argote, 1999), which fosters a need for creating knowledge internally (Nonaka, 1994). However, with respect to both modes of knowledge sourcing, the capacity to absorb knowledge has become crucial.

In their seminal papers, Cohen and Levinthal define absorptive capacity (henceforth, “AC”) as the "ability to identify, assimilate, and exploit knowledge from the environment” (1989: 589, 1990, 1994). The increasing number of publications that apply, measure or extend their concept of AC definitely reflects the high absorption of the relatively new AC notion in the organization field. Scholars have "recognized" the richness of the concept and "assimilated" the concept through renewing theories, developing conceptual models, and conducting various empirical studies. However, there are serious doubts about the exploitation of the concept to its full potential in the organization field. Van den Bosch, Van Wijk and Volberda (2003) classify AC as a potentially powerful multilevel and transdisciplinary construct, but identify a huge gap between the speed of proliferation of theoretical and empirical contributions and the speed of accumulation of the acquired scientific knowledge regarding AC. Lane, Koka and Pathak (2006) even conclude that the AC construct has become reified - the construct is taken for granted and researchers fail to specify the underlying assumptions - with devastating effects on the validity of studies that use the AC concept.

How can we fully exploit the AC concept and explore future fruitful extensions of the concept? In this Perspective Paper, we first study the roots of absorptive capacity by systematizing its underlying theories. What have prior AC studies in the organization field have brought us? Research on AC spans theories of learning, innovation, managerial cognition, the knowledge-based view of the firm, dynamic capabilities and co-evolutionary theories. This diversity in theories and empirical methods has contributed to the rapid advance of the emerging AC field by cultivating the simultaneous development of specialized areas of inquiry that investigate different dimensions, antecedents, levels of analysis and outcomes of AC and contextual factors that affect AC. 
However, without addressing the questions of integration, the organization field runs the risk of propagating a highly fractioned view of AC (cf. Argote et al., 2003). Are there points of convergence in the AC field? Are these theories and empirical studies investigating unrelated aspects of AC or are they treading the same ground? Given the size and diversity of the AC literature, we will map the existing terrain of research in AC on the basis of a comprehensive bibliometric analysis. By identifying the relevant domains in the AC field that attract most publications and their specific growth rates, we were able to provide a first overview of the field and predict its further development. It mainly shows that key antecedents to absorptive capacity itself have not received much attention, in particular intraorganizational antecedents. Moreover, studies on the exploitation of knowledge from the environment and intangible outcomes are underrepresented in the field. Cohen and Levinthal, and virtually all of the subsequent AC literature, essentially argue that AC is mainly dependent on firms' prior knowledge endowments, which in turn are dependent on earlier AC. On the basis of the insights of our literature review and bibliometric cartography, we argue that $\mathrm{AC}$ has an important, but hitherto neglected, set of distinctly organizational antecedents, such as organizational structure, reward systems, and systems of HRM practices and policies. Although Cohen and Levinthal (1990) explicitly point out that aspects that are "distinctly organizational" shape a firm's AC beyond the sum of employees' individual absorptive capacities, they do not treat this in much detail, and understanding of such organizational antecedents of AC remains limited. Moreover, there may be antecedents of AC that are placed at the level of individuals. These antecedents have been similarly neglected in the literature, and because of this, we have little knowledge of the effect of, for example, personnel turnover on AC and key individuals' impact on AC.

On the basis of the outcomes of the bibliometric analysis, we propose an integrative framework that highlights the underlying dimensions of AC, its multi-level antecedents, the contextual factors that affect AC and the outcomes of AC. The framework identifies common areas of research that should be further developed in the organization field. In particular, we provide some directions for further research regarding the boundaries of the construct, its individual and organizational-level antecedents, inward and outward-looking dimensions, and costs aspects of AC. With more research efforts in these so-called micro-foundations of AC, managers can utilize their knowledge of organizational antecedents to influence future outcomes such as competitive advantage, innovation, and firm performance. 


\section{Absorptive Capacity in Organizational Theories: A Review}

In their study on international technology transfer ${ }^{1}$, Kedia and Bhagat (1988) first coined the term “absorptive capacity”. However, the contribution by Cohen and Levinthal (1990) is generally accepted as the founding paper. It defined AC as "the ability of a firm to recognize the value of new, external information, assimilate it, and apply it to commercial ends” (Cohen and Levinthal, 1990: 128). This seminal paper has received more than 1,300 citations, and there are more than 600 papers published incorporating the concept of AC in ISI journals. Cohen and Levinthal $(1989,1990)$ put R\&D at the center of firms' innovative processes by linking it to both learning and innovation. In doing so, they positioned $\mathrm{AC}$ as a key concept in the literature and laid the groundwork for theoretical developments over the subsequent 19 years, as summarized in Table $1 .^{2}$ However, the AC theme overlaps with other themes and fields, such as cognition, knowledge and dynamic capabilities. Moreover, the theoretical development of AC ranges from the psychological emphasis on cognition and learning to the economic perspective on innovation and competition to the sociological orientation towards co-evolution. In this section, we briefly discuss how various streams in the organization field are related to $\mathrm{AC}$, in some cases even partially anticipating it.

Insert Table 1 about here

Learning. The roots of AC are found in the organizational learning literature of the 1980s. Fiol and Lyles (1985) and Levitt and March (1988) discuss the role of R\&D in organizational learning and performance, while Kedia and Bhagat (1988) address the role of organizational characteristics in technology transfer. In line with Cohen and Levinthal (1990), these early articles strongly link AC to learning, innovation and performance of firms.

Cohen and Levinthal (1990: 135) also posit that distinct organizational mechanism can influence the level of AC, such as the transfer of knowledge across and within units, the structure of communication between the external environment and the firm (i.e. the centralization of the interface function), a broad and active network of internal and external relationships, and cross-function interfaces (cf. Van den

\footnotetext{
${ }^{1}$ In economics, Stiglitz's (1987) notion of "learning to learn" is clearly a precursor of AC, as is David's (1975) analysis of localized technological progress.

${ }^{2}$ Some of the literature streams summarized here (i.e. organizational learning, innovation, the knowledge-based view, and dynamic capabilities) overlap with those addressed or touched upon in the review paper by Lane, Koka, and Pathak (2006). The other two (managerial cognition and co-evolution) are implicit in their review, but not incorporated in their model.
} 
Bosch, Volberda and De Boer, 1999). However, their main argument is that the learning potential for AC is primarily determined by prior related knowledge and $R \& D$ investments, labeled as the "cumulativeness feature” by Cohen and Levinthal. Many empirical studies support this (recursive) notion of AC (Ahuja, 2000; Cockburn and Henderson, 1998; Lane and Lubatkin, 1998; Lyles and Salk, 1996; Mowery et al., 1996; Pennings and Harianto, 1992; Pisano, 1994; Powell et al., 1996; Shane, 2000; Stuart, 1998; Tsai, 2001). Furthermore, Reagans and McEvily (2003: 243) support the concept of knowledge accumulation by showing that people absorb knowledge more easily when they already have some common knowledge in terms of expertise, training or back ground characteristics.

However, some subsequent work looks at $\mathrm{AC}$ in an inter-organizational context (Lane and Lubatkin, 1998; Lane, Salk and Lyles, 2001). When knowledge is shared or transferred between firms, $R \& D$ is less relevant than the similarity between the firms. Lane and Lubatkin (1998) coin the term "relative absorptive capacity" to describe the phenomenon that firms have various levels of AC and that it is a relative phenomenon. Lane et al. (2001) develop measures for the three processes within AC of recognition, assimilation, and utilization. The empirical analysis indicates that recognition and assimilation have an impact on the knowledge acquired, and utilization has a direct positive link to firm performance.

Innovation. Insights from the innovation literature, which grows out of both the management and the economics literatures, clearly play an important role in Cohen and Levinthal's (1989) prelude to AC. The primary conclusion of that paper is that while investments in R\&D are clearly aimed at generating innovations and also fulfill this task, an important by-product is the expansion of firms' "capabilities to assimilate and exploit externally available information” (Cohen and Levinthal, 1989: 593). In line with this, Feinberg and Gupta (2004) studied the role of knowledge spillovers in R\&D location choice by MNCs and suggested that MNCs anticipate knowledge spillovers from their competition when they make decisions about R\&D responsibilities abroad. They found that “... the MNCs view the assignment of R\&D responsibilities to a subsidiary as an investment in the subsidiary's capacity not only to create new technical knowledge but also to absorb spillovers of external knowledge from competitors” (2004: 842).

While modified to a definition with three components (recognition, assimilation, and exploitation) in their 1990 paper and further expanded by Zahra and George (2002) in four (acquisition, assimilation, transformation, and exploitation), the groundwork for the AC concept was laid in Cohen and Levinthal's 1989 paper. In their 1990 paper, Cohen and Levinthal not only include recognition of knowledge, but also link AC more strongly to R\&D, innovation, and learning. Moreover, Cockburn and Henderson (1998) included organizational antecedents in the context of pharmaceutical research and 
further broadened the innovation perspective on AC. They found that AC is related to firms' internal organization, as well as their performance in drug discovery.

Managerial Cognition. Theory on managerial cognition suggests that managers perceive things through their own cognitive lenses. Thus, managers can be considered as "cognizers" (Calori, Johnson, and Sarnin, 1994), who reduce the complexity they face by developing mental maps that result in a “dominant management logic" (Prahalad and Bettis, 1986; Bettis and Prahalad, 1995). This dominant logic evolves over time, directly influencing the organizational form (Dijksterhuis, Van den Bosch, and Volberda, 1999) and indirectly the level of AC (Van den Bosch et al, 1999). For example, managers applying a classical management logic (Dijksterhuis et al., 1999: 572; Volberda, 1998) favor traditional functional organizational forms and do not consider the environment as a source of valuable knowledge to be absorbed (Van den Bosch et al., 1999: 560). In such a classical management logic, managers portray organizations as tools designed to achieve preset ends and ignore or minimize the perturbations and opportunities posed by connections to a wider environment (Scott, 1987). Therefore, these managers will seriously limit the level of absorptive capacity of the firm. Lenox and King (2004) show that managers can however directly affect a firm's absorptive capacity for a new practice by providing information to potential adopters in the organization. The effectiveness of these managerial actions is contingent on the degree to which other sources of information are available to individuals. Previous adopters and past events seem to dampen the effect of central information, while related experiences seem to amplify it. Minbaeva et al. (2003) emphasize the importance of individuals' ability (education and skills) as well their motivation to absorb external knowledge. As managers continuously develop theories about the world around them and embed them in their dominant logic (Sanchez, 2001), firm AC will be strongly influenced by cognitive processes on the managerial level. This is consistent with Van den Bosch and Van Wijk's (2001) plea to recognize the strong effect managers can have on knowledge-related processes in organizations.

Knowledge-based View of the Firm. Starting with Kogut and Zander (1992), the knowledgebased view considers knowledge to be the most important resource of the firm and the main determinant of competitive advantage. This view strongly influences the relevance of the AC construct, as AC is key to developing and increasing a firm's knowledge base. In the particular case of knowledge-intensive firms, learning at the organizational and individual level is of prime importance (Starbuck, 1992). Thus, AC involves individuals, groups, and organizational levels. Individuals are involved in the knowledge sharing and recognition aspects, but at the organizational level, routines, histories and stories, documentation, procedures, heuristics and know-how are important in creating shared understandings of the knowledge at the firm level (Grant, 1996b; Matusik and Heeley, 2005). 
Knowledge stocks and flows are also constructs that are related to the recognition, assimilation and utilization of new knowledge (Foss, 2006). A number of researchers have used "knowledge stock" concepts and measures to access firm-level AC. For example, Nicholls-Nixon (1993) examines AC in the pharmaceutical industry by using the number of patents, number of new products, and the firm's reputation as measures of AC. Those with higher levels of AC utilized more alliances and had more inhouse expertise than those with lower levels.

Knowledge flows involve the transfer of knowledge to the receiver. Theorists suggest that the AC of sender and receiver, the past experiences, and the degree of related knowledge, are some of the most important factors influencing the success of knowledge transfer. Thus, Cohen and Levinthal (1990) point out that learning is dependent on the degree of knowledge overlap between two parties (see also Lane and Lubatkin, 1998). Using patent data, Rosenkopf and Almeida (2003) show a tendency for firms to search locally for new knowledge (cf. also David, 1975; Nelson and Winter, 1982; Stiglitz, 1987). Local knowledge can be "more easily recognized and managed by the organization's existing routines and members" (Rosenkopf and Almeida, 2003: 753). At the same time, they propose that connections between firms in dissimilar contexts may present more novel and non-redundant knowledge. Knowledge is more likely to be transferred between people with similar training and backgrounds. Lane and Lubatkin (1998) suggest that those firms with basic scientific knowledge similarities with their partners report more learning. They shift the emphasis to a dyad with one firm learning from another where one may be the teacher and the other the student. They use a sample of R\&D alliances between pharmaceutical and biotechnology companies to test whether similarities in organizational practices and in knowledge influence the ability to absorb new knowledge. Their main conclusion is that the AC of the student firm is as important as the AC of the teacher firm and that organizational antecedents are important.

Van den Bosch, Volberda, and De Boer (1999) emphasize that the characteristics of a firm's AC relate to the nature of the knowledge in its environment. They support Cohen and Levinthal's notion (1990: 150) that: “Absorptive capacity is more likely to be developed and maintained as a byproduct of routine activity when the knowledge domain that the firm wishes to exploit is closely related to its current knowledge base”. However, they show that knowledge embedded in the organizational form (Grant, 1996b) as well as the firm's combinative capabilities (Kogut and Zander, 1992) influence a firm's AC. Not only limitations in a firm's current knowledge base, but also the rigidity of organization forms and the combinative capabilities to synthesize and apply current and acquired knowledge may generate inertia in adapting AC. Van Wijk, Van den Bosch, and Volberda (2003) and Malhotra, Gosain, and El Sawy (2005) show that interorganizational networks and supply chains can be rewarding for firms to gain access to knowledge, to facilitate learning processes, and to foster knowledge creation. Furthermore, from 
an internal network perspective, Andersen and Foss (2005) find that the development of strategic opportunities is increased by internal communication between business units, establishing clearly the relevance of knowledge transfer and AC within multi-unit firms.

Dynamic Capabilities. Dynamic capabilities represent the firm's latent abilities to renew, augment, and adapt its core competence over time (Teece, Pisano, and Shuen, 1997). In their 1990 paper, Cohen and Levinthal point out that “....an organization’s absorptive capacity is not resident in any single individual but depends on the link across a mosaic of individual capabilities" (Cohen and Levinthal, 1990: 133). In their 1994 article, they argued that sustaining this capability over time requires investments, but results in the ability to not only "exploit new, valuable developments, but also to envision better their emergence" (Cohen and Levinthal, 1994: 244). Extending this dynamic nature further, Zahra and George (2002) introduce a “dynamic capabilities” perspective of AC and distinguish among four dimensions of AC that constitute potential and realized AC. The distinction highlights the separate, but complementary roles of both subsets of AC. Firms focusing on acquisition and assimilation of new external knowledge are able to continuously renew their knowledge stock (potential AC), but they may suffer from the costs of acquisition without gaining the benefits of exploitation. Conversely, firms focusing on transformation and exploitation (realized AC) may achieve short-term profits through exploitation but fall into a competence trap. Todorova and Durisin (2007) provide a review of Zahra and George's (2002) reconceptualization of AC and suggest that Cohen and Levinthal's 1990 model provides important implications left out in Zahra and George's model. They identify important antecedents such as social integration, appropriability regimes, feedback loops, and power relationships. Moreover, they suggest to go back to the component capabilities (recognition, acquisition, assimilation or transformation depending on the current cognitive frame of reference, and exploitation) instead of the subsets of potential and realized AC. Jansen, Van den Bosch, and Volberda (2005) provide evidence of the distinct effects of organizational antecedents on the components of AC. They show in an empirical study within a multi-unit firm that coordination capabilities, such as "cross-functional interfaces, participation in decision-making, and job rotation" (2005: 999) enhance potential AC, while systems capabilities such as "formalization" and socialization capabilities, such as "connectedness and socialization tactics" (2005: 999) strengthen realized AC at the business unit level.

Co-Evolution. According to co-evolutionary theory, firm change is the joint effect of managerial intentionality, institutional and environmental effects (Lewin and Volberda, 1999; Volberda and Lewin, 2003). Many co-evolutionary studies suggest that AC enables or restricts the level and range of exploration adaptations (Cohen and Levinthal, 1990, 1994, 1997; Lewin et al., 1999). For instance, Cohen and Levinthal suggested that firms can benefit from investing in AC to pre-empt changes in the 
environment (1994: 244). Furthermore, Lewin et al. (1999) take AC to mediate the relationships between managerial action, competitive dynamics and the institutional environment, as well as the relationship between exploration, exploitation, firm-specific history, and wealth creation (1999: 536-537). Moreover, Van den Bosch et al. (1999) study the co-evolution of a firm's path-dependent AC and the knowledge environment. They show various co-evolutionairy effects, such as the higher AC, the more likely a firm's expectation formation will be defined in terms of the opportunities present in its environment, independent of current performance criteria. All in all, co-evolutionary theories implicitly or explicitly build on Cohen and Levinthal's (1990) concept of AC, if only because they integrate the other theoretical streams discussed above (Volberda et al., 2001). Their main argument is that a firm's level of AC is the joint outcome of managerial actions and developments in the knowledge-environment.

Our theory overview clearly shows that the concept of AC has been resonating in various organization theories. While most of the underlying studies are still firmly embodied in the themes of organizational learning and innovation and the definitions developed by Cohen and Levinthal (1989, 1990, 1994), AC research has also addressed knowledge characteristics, managerial cognition, capability development, organizational structure and scope, as well as inter-organizational learning in the contexts of dyads and networks. The heterogeneity of AC research is for sure an indication of the richness of the construct. However, it also raises important questions about the degree of integration across theories and the extent to which a truly cumulative body of knowledge is emerging. In the next section, we investigate to what extent the AC concept has been absorbed in empirical studies.

\section{Absorptive Capacity in Empirical Studies}

Empirical studies, using different methods (surveys, archival data, case-studies), and studying different contexts (firms, joint ventures, different industries) are increasing our understanding of AC. The reliance on different theoretical perspectives, different empirical methods, and different empirical contexts of AC helps establish the extent to which findings generalize and to identify the boundary conditions under which they apply. While our intent is not to identify all of the empirical research that is directly or tangentially related to AC, a few observations are in order regarding the empirical work done to date.

Static Approach. In these empirical studies, AC is typically viewed as a firm-level concept that captures the evolution of learning and utilization of new knowledge that accumulates over time. They reinforce Cohen and Levinthal's definition indicating that AC is developmental, lagged, and pathdependent. However, we find that very few published empirical studies of AC fully capture the developmental, lagged, and path-dependent characteristics of AC. Despite the lack of research on these 
characteristics of AC, most authors continue to frame their arguments in a very static way. Their analytical models do not take into account time and feedback loops (cf. Todorova and Durisin, 2007; Van den Bosch et al., 1999). The study of AC in a dynamic way requires the use of longitudinal research methods and process models, which allow investigating the pace and paths of change. Some studies do capture some portion of these characteristics. Feinberg and Gupta (2004) used large-scale panel data over a seven-year period to study R\&D subsidiaries of MNCs and their assignment of new R\&D units. Lenox and King (2004) utilize independent variables such as Past Events and Related Practices and find that past experience may influence the recognition and utilization of new knowledge. Lane et. al. (2001) are able to use two time periods and to use a variable showing prior knowledge learned and the impact on current utilization of new knowledge. In our view, these studies do capture the characteristics, but still leave room for many other factors that affect the AC of firms, including organizational factors that can be influenced through managerial choice. We do need more dynamic models that incorporate variables addressing managerial intentionality to influence the level of AC (Van den Bosch et al., 2003). Little is also known about how knowledge is stored and retrieved from the organizational memory, and how this varies over time.

Indirect Measures. Measures of AC have been rudimentary and do not fully reflect the richness of the construct. The majority of AC empirical studies use proxies (such as R\&D expenditures or the number of scientists working in R\&D departments) rather than direct measures of the construct (cf. Zahra and George, 2002; Minbaeva et al., 2003). Archival data proxies are attractive in research, as they can often be obtained more efficiently than direct measures. However, they may provide less accurate representations. As Mowery et al. (1996: 82) pointed out: "R\&D intensity measures inputs to the creation of capabilities and indicates little if anything about resultant change in capabilities”. Lane and Lubatkin (1998) provided empirical evidence about the relatively low explanatory power of R\&D spending in comparison to the explanatory power of their three dimensions of AC. Furthermore, linkage to the dynamic nature of capabilities is missing.

Absorptive Capacity as Independent Variable. Although Cohen and Levinthal (1990) used $\mathrm{R} \& \mathrm{D}$ spending as a firm-level proxy for AC, they suggested that there are organizational mechanisms that influence AC such as the transfer of knowledge, centralization, internal networks, and cross-functional interfaces. Most empirical studies however considered AC as an independent variable. Few studies have broken AC down into its components and measured elements of recognition, assimilation and utilization separately, with the exception of Lane et al. (2001) and Jansen et al. (2005).

One Level of Analysis. AC is a multilevel construct and should be studied at the individual, unit, firm, and inter-firm level of analysis. As Cohen and Levinthal (1990: 128) pointed out: "Outside sources 
of knowledge are often critical to the innovation process, whatever the organizational level at which the innovating unit is defined". Of these levels of analysis, the majority of empirical studies on AC address either the business unit level (cf. Tsai, 2001) or the subsidiary level (cf. Gupta and Govindarajan, 2000).

Uni-dimensional Operationalizations. Furthermore, few studies have truly assessed the multidimensional nature of AC. Most empirical studies focus primarily on prior related knowledge and ignore various internal mechanisms that can influence a firm's level of AC, such as the structure of communication and the character and distribution of expertise and knowledge within the organization. Multidimensional characterizations of AC are important because they can explain more variance. An exception is Van den Bosch et al. (1999), who on the basis of case studies find that organizational forms and combinative capabilities are internal mechanisms to raise levels of AC. Moreover, they suggest that AC may be affected by the internal organization structure and that different divisions/units may be able to absorb different kinds of knowledge but also may have different capabilities for transferring that knowledge internally. In addition, Jansen et al. (2005) showed on the basis of a survey in a large multiunit firm how various organizational mechanisms associated with coordination capabilities (crossfunctional interfaces, participation in decision-making, job rotation), systems capabilities (formalization, routinization) and socialization capabilities (connectedness, socialization tactics) impact differently on AC.

Ignorance of Process Dimensions. It is clear that most empirical studies do not carefully address important processes that influence the viability of AC constructs. For example, organizational memory is important because past knowledge is seen as the basis for new knowledge. But how knowledge is stored and retrieved is not addressed (Lyles and Schwenk, 1992) nor is the question how long lived is the stored knowledge. The concept of knowledge stock is not fully addressed in most studies and is often measured by the number of patents a company holds (Rosenkopf and Almeida, 2003). Furthermore, many aspects of the learning processes are presented but not fully utilized by empirical researchers as aspects of AC. For example, additional work can be done on creativity, innovation, improvisation, and chunking of knowledge.

Although empirical studies in AC show serious shortcomings, they certainly contributed to the rapid advance of the emerging AC field by investigating different dimensions, antecedents, levels of analysis and outcomes of AC as well as contextual factors that affect AC. In the remainder of this paper, we assess the state of integration of knowledge accumulated across the different theoretical perspectives and empirical studies (cf. Argote et al., 2003). Are there points of convergence in the AC field? We also address what we see as the primary research gaps. 


\section{A Bibliometric Analysis of Absorptive Capacity}

So far, we have provided a comprehensive review of underlying theories and the most essential empirical studies of AC. Do we see stable and consistent findings from one discipline that are replicated and reinforced by findings from other disciplines? Are researchers from different disciplines investigating unrelated aspects of AC or are they treading the same ground? What are the current themes emerging from AC research? Given the size and diversity of the AC literature, we conducted a comprehensive bibliometric analysis of the AC concept in the organizational literature. In every scientific field there are key concepts that set the base for theoretical developments through the years. The object of our bibliometric study is analyzing the influence of the introduction of the AC concept on the research field through the analysis of scientific publications. By mapping the existing terrain of research in AC, we were able to answer the following questions:

- What concepts of AC have been used throughout the organization literature?

- What is the diffusion rate throughout the organization literature?

This analysis (performed by the Centre for Science and Technology Studies, Leyden University) identifies the linkage between AC and various key words based on 1213 publications from the 1992-2005 period. It mainly maps the structure of all publications citing Cohen and Levinthal (1990) by applying a co-occurrence bibliometric mapping method. With this method we could create a 2-dimensional landscape with sub-domains representing topic clusters. The topic clusters are created by applying a coword analysis to the keywords in the citing publications. The distances between topic clusters represent their mutual cognitive similarity.

We collected the keywords of these 1213 publications (keywords plus author keywords) to assess the content of the field of AC. Of the 94 most frequent keywords (with 20 or more occurrences) we selected the 83 most relevant and discriminative. With these 83 keywords, we calculated the number of times they co-occur in publications. With this information, we applied a clustering analysis to identify 11 clusters of topics. For instance, the key-words alliances, collaboration, cooperation, joint ventures, embeddedness, networks, strategic alliances formed a clear topic cluster and we refer to it as sub-domain "inter-organizational antecedents". The key-words growth, investment, productivity, FDI, patents, technology transfer, performance, and sustained competitive advantage represent the sub-domain "tangible outcome variables of AC". In addition, we defined the overlap between the clusters (publications may be represented in more than one sub-domain). This overlap was used to create the map as shown below (see Figure 1). The resulting bibliometric cartography (Noyons and Van Raan, 1998a; Noyons and Van Raan, 1998b, Noyons et al., 1999) groups co-occurring keywords into clusters and maps 
those clusters in a two-dimensional figure, with the size of each cluster indicating the number of publications represented and the color of each cluster indicating the growth in the number of publications over the period 1992-2005 (black: fast growth; grey: growth around average; white: growth below average). Clusters that are closer to one another co-occur more often than clusters that are further apart. The topics that appear most frequently in AC papers during the period 1992-2005 are graphed in Figure 1.

Insert Figure 1 about here

It is quite clear from Figure 1 that the bulk of studies focus on R\&D rates in various industries (cluster 9), with a strong focus on technology and innovation. Upcoming growth areas of AC are studies on knowledge flows and dynamic capabilities (cluster 6), the impact of AC on technological innovation and firm performance (cluster 10), and the effects of relational (trust) versus formal governance modes (cluster 7) on AC (the black circles). Figure 1 also shows that in the period 1992-2005 organizational innovation and realized AC have been underrepresented (the white circles), as they occurred fewer than other AC-related concepts and experienced slower than average growth. These clusters are positioned away from the others, indicating that they have been studied less often with other AC-related topics than the other topics. Topics addressing the micro-foundations of AC have hardly been published during the 1992-2005 period, with hardly any keywords relating to individuals and managers in 14 years. Cluster 8 , while small, may show some promise here, as it addresses intra-organizational antecedents to AC and as such could provide a starting point for further development of the micro-foundations of AC such as organization form, informal networks, personnel, and leveraging across units. However, the growth of the number of AC studies on micro-foundations is quite limited compared to other clusters.

Insert Figure 2 about here

As discussed in the previous sections and supported by Figure 1, much effort has been devoted to the managerial and inter-organizational antecedents of AC. Compared to the intra-organizational antecedents, the growth of research into the managerial as well as the inter-organizational antecedents of AC has been much stronger in the field (see Figure 2). The moderating effects of contextual factors such as industry dynamics and environmental conditions (level of competitiveness and dynamism) have also received much attention (cluster 4 in Figure 1). While a focus on relatively straightforward topics and 
tangible outcome variables such as patents, $R \& D$ investments, productivity and firm growth is clearly relevant (cluster 5), Figure 1 shows that other areas have been neglected, with some of them - such as organizational innovation and realized AC - still receiving limited attention. Zahra and George (2002) and Jansen et al. (2005) have addressed realized AC, but more contributions are necessary. Apparently, studies on knowledge recognition and to a lesser extent assimilation are dominating the field, while studies on knowledge exploitation are underrepresented. Discussing AC merely as a capacity without discussing the actual processes that link it to outcome variables such as patents, innovation, and performance cannot be regarded as an integrative approach. Similarly, studies that investigate the multidirectional effects of AC on organizational innovation in terms of reconfiguring the firm's value chain, changing its business model, and redesigning the organizational forms have been very limited in the organization field. Instead, studies on R\&D and technological innovation dominate in the field.

Figures 3 and 4 plot the number of papers studying "realized AC" and "organizational innovation" against those studying the topics of "knowledge flows and capabilities" and "technological innovation and firm performance". While the latter topics have also been relatively under-researched, it is clear that AC studies focusing on knowledge flows, capabilities, technological innovation and firm performance have clearly experienced strong growth since the late 1990s.

Insert Figure 3 about here

Insert Figure 4 about here

However, Figure 5 shows that the diffusion of studies that focus on tangible outcome variables, such as FDI, patents, R\&D investments, and knowledge transfer, is much higher than those that focus on innovation and firm performance.

Insert Figure 5 about here

Our bibliometric analysis clearly shows that AC studies so far have overemphasized R\&D rates, various environmental contexts for AC, interorganizational antecedents of AC such as alliances and joint ventures 
and the tangible outcomes of AC in terms of FDI and patents. On the other hand, the intra-organizational antecedents of $\mathrm{AC}$, the exploitation process of knowledge from the environment and the intangible outcomes have received considerably less attention in the field. By contrast, research on knowledge flows and capabilities and their differential effect on AC as well the effects of AC on technological innovation and firm performance is fastly growing. On the basis of these clear gaps as presented in our bibliometric cartography, we will develop an integrative model taking into account the micro-foundations of AC (particularly the intra-organizational antecedents), the various processes of AC (not only recognition and assimilation, but also exploitation), and the various outcomes of AC (not only tangible outcomes).

\section{An Integrative Framework of Absorptive Capacity}

The highly differentiated nature of AC is a hallmark of the field and is evident in the multitude of theoretical perspectives and empirical constructs brought to bear on the topic. The various underlying theoretical constructs and empirical variables as systematized in Table 1 and Figure 1 provide us with numerous antecedents, dimensions, mediators, moderators and outcomes of AC. In spite of this diversity of theories, methods, and empirical studies, there is a need for integration and accumulation of knowledge across research efforts in AC. To facilitate accumulation of knowledge, we propose an integrative framework that highlights the main building blocks and outcomes of AC (see Figure 6). The framework identifies common areas of research in terms of the multi-level antecedents of AC (managerial, intraorganizational, inter-organizational, and prior related knowledge), process dimensions of AC (acquisition, assimilation, transformation, and exploitation), outcomes of AC (competitive advantage, innovation, performance) and contextual factors that affect AC (turbulence of the knowledge environment). The framework of Figure 6 also points to several emerging themes that cut across different research traditions or that have been under-researched. But most importantly, the framework is used to identify where research findings about AC converge and where gaps in our understanding exist. Below we discuss the building blocks of AC.

\section{Insert Figure 6 about here}

Managerial Antecedents of Absorptive Capacity. Except in the case of one-man firms or very small organizations, an organization's AC is not resident in any single individual, but depends on the links across a mosaic of individual capabilities (Cohen and Levinthal, 1990: 133). AC requires porous boundaries, scanning broadly for new knowledge, and identifying and using those employees who serve 
as gatekeepers and boundary spanners (Volberda, 1996). Management capabilities may synthesize and apply current and acquired knowledge and may be influenced and limited by the cognitions and dominant logics of managers. In line with Adner and Helfat (2003: 1012), a dynamic managerial capability refers to the capacity of managers to create, extend or modify the knowledge resource base of an organization. Examples of these managerial capabilities and skills are the structure of communication, the character and distribution of expertise, gate-keeping or boundary-spanning roles, cross-functional interfaces and jobrotation. We need more research on the relative effect of these management skills and capabilities on AC. Moreover, there are important complementarities between these set of managerial capabilities. For instance, Jansen et al. (2005) studied the separate and joint impact of different combinative capabilities: coordination, systems and socialization capabilities and their differential effect on AC. Moreover, various formal and informal managerial incentives may differently influence AC and knowledge sharing. Besides managerial capabilities and incentives, firm AC will be strongly influenced by cognitive processes on the managerial level and existing dominant logics of management teams (Mom, Van den Bosch and Volberda, 2007).

Intra-organizational Antecedents of Absorptive Capacity. A firm's knowledge base cannot be separated from how it is currently organized (Grant, 1996b). An organization form can be viewed as a structure that carries out multiple knowledge-related tasks, such as evaluating, assimilating, integrating, utilizing, and building knowledge (Loasby, 1976). Given this overall insight, various multi-unit organization forms differently influence the level and type of AC (Van den Bosch et al., 1999).

Issues of internal informal networks are also important for the identification and assimilation of new knowledge. Dhanaraj et al. (2004) identify the importance of social embeddedness in transferring tacit and explicit knowledge. Thus networks of individuals influence what knowledge is shared or assimilated. For instance, AC can be transferred through hiring new personnel or corporate acquisitions. Unit structure, firm size and informal networks are the source of heterogeneity of AC. The lack of research regarding intra-organizational antecedents is surprising, especially since Cohen and Levinthal (1990) emphasized the importance of organizational mechanisms and suggested considering what aspects of absorptive capacity are distinctly organizational. Even when organizational antecedents have been considered (Lane et al., 2001), their relationships with different dimensions of AC have not been tested empirically.

Inter-organizational Antecedents of Absorptive Capacity. Gaining knowledge from external sources and learning from partners are critical parts of the inter-organizational antecedents of AC. The path dependent and often tacit nature of a firm's idiosyncratic prior related knowledge and organizational context may limit quick integration of outside acquired AC. At the same time, if there is some overlap of 
knowledge, it may make the assimilation of the knowledge proceed more easily. AC studies into various inter-organizational antecedents may provide insights into the costs of assimilating and exploiting knowledge from corporate research ventures versus strategic alliances and joint ventures. Also, social embeddedness, network position, and other factors influence the inter-organizational antecedents of AC. Research into various inter-organizational arrangements such as industry clusters, strategic groups and networks may show the different effects on the various dimensions of AC.

Prior Related Knowledge. While Cohen and Levinthal's (1990) statement that prior related knowledge is the most important antecedent to AC has been accepted by many, its importance has been challenged in more recent contributions to the literature (cf. Van den Bosch et al., 1999). Moreover, little is known about how the stock of prior knowledge is stored and retrieved. Computer databases or routines are two mechanism for storing prior knowledge, but there are also many other avenues that are more tacit such as stories, norms, etc., that would influence how prior knowledge would be retrieved and stored. Lenox and King (2004) suggest that prior related knowledge must be distributed throughout the organization to have the largest possible influence on the future development of AC. As our understanding of the knowledge absorption on lower levels of analysis (such as the group and the individual) is at best limited, the process that connects prior related knowledge with firm-level AC remains unclear. External knowledge that is absorbed by the organization should reach the right individuals at the right time. Similarly, the organization needs to apply prior related knowledge that resides in its employees.

Absorptive Capacity Process. Despite the growing interest in AC, few have captured the richness and multidimensionality of the AC process. Few studies address the processes in detail and how they change over time. In addition, various process dimensions have been suggested, ranging from Cohen \& Levinthal's well-known dimensions of recognition, assimilation, and exploitation (1990), Zahra and George's (2002) four dimensions that constitute potential and realized AC, Lane et al.'s (2006) three process dimensions of exploratory learning, transformative learning, and exploitative learning to Todorova and Durisin's (2007) recognition, acquisition, assimilation or transformation, and exploitation. Examining differing effects of organizational antecedents on AC process dimensions would not only clarify how AC can be developed, but also reveal why firms have difficulties in managing dimensions of AC successfully. Moreover, the underlying tensions between these process dimensions of AC deserve more attention. High levels of acquisition and assimilation of knowledge might be detrimental to the firms' ability to transform and exploit knowledge.

Environmental Conditions. Both the managerial cognition literature (e.g. Dijksterhuis et al. 1999) and the knowledge-based view (e.g. Van den Bosch et al., 1999) indicate that the characteristics of 
the knowledge environment influence the nature of a firm's AC. When the knowledge environment is turbulent, firms tend to develop AC aimed at exploration, with low efficiency, a broad scope, and much flexibility. When the knowledge environment is stable, firms tend to develop AC aimed at exploitation, with high efficiency, a narrow scope and little flexibility (Van den Bosch et al., 1999). These ideas, while interesting, are illustrated with case studies only and need to be tested in a large- $\mathrm{N}$ context. Also, the moderating effect of various contextual factors (competitiveness, dynamism, knowledge characteristics) and regimes of appropriability on the relationship between antecedents, AC and performance requires more research. Cohen and Levinthal (1990) show negative moderating effects of appropriability on the relationship between antecedents and AC, implying that AC increases with weak regimes and competitive spillovers. Zahra and George (2002) however propose positive moderating effects between AC and performance because strong regimes help to sustain competitive advantage.

Outcomes of Absorptive Capacity. Absorptive capacity is seen as an explanation of competitive advantage (Cohen and Levinthal, 1989, 1990), innovation (Stock et al., 2001), exploitation/exploration orientation (Lewin et al., 1999), and firm performance (Lane et al., 2001; Tsai, 2001). While most studies have focused on the tangible outcomes, AC also seems to result in intangible outcomes, such as intraorganizational transfer of knowledge (Gupta and Govindarajan, 2000), interorganizational learning (Lane et al., 2001), and knowledge search (Shenkar and Li, 1999). Moreover, Cohen and Levinthal (1990) pointed out that $\mathrm{AC}$ affects expectation formation and the aspiration level of the firm, permitting the firm to predict more accurately the nature and commercial potential of technological advances. They suggest that the higher the level of AC, the more likely it is that a firm will be proactive in exploiting opportunities present in the environment, independent of current performance. Obviously, these outcomes are of great importance for strategy and organization research. But we need to know more about the specific outcomes and pay-offs of AC. AC most likely has positive outcomes, but firms can also have too much AC. Firms focusing too much on knowledge acquisition and assimilation are able to continuously renew their knowledge stock, but they may suffer from the costs of acquisition without gaining benefits of exploitation (Zahra and George, 2002). Conversely, firms focusing on transformation and exploitation may achieve short-term benefits but fall into a competence trap (Ahuja and Lampert, 2001; Jansen et al., 2005)

The framework as discussed above identifies common areas of research that should be further developed in the organization field. We especially encourage research that focuses on patterns of coherent, interlinked changes in constructs of our integrative framework rather than simple pairwise performance relationships. While this complementarity perspective is consistent with the emphasis on "systemic" change among the multi-level antecedents and various knowledge processes of our 
framework, the relevant complementarities for enhancing absorptive capacity and innovation performance are still rarely investigated in theory and practice (Roberts, 2004; Whittington et al., 1999). In particular, future research should focus on those complementarities that relate to these interactions that simultaneously take place - within and between the multi-level antecedents, knowledge stocks, absorptive capacity processes, and environmental conditions - that have a major positive impact on absorptive capacity and performance.

\section{Directions for Future Research: Systematizing Research on Gaps}

There is little doubt that AC has been one of the most cited and used - and in this sense, one of the most important - constructs to emerge in the management literature in the last two decades. It is a concept that is cognitively appealing as an organizational attribute which captures learning capability, knowledge retention and utilization. Our paper highlights extensive research utilizing the AC concept and enhancing our understanding of it. At the same time, our paper shows that the AC construct is still surrounded by considerable ambiguity with respect to its meaning and nature, the domain(s) in which it exists, its implications and antecedents, including its micro-foundations in individual action and interaction. For example, while the previous sections identified the antecedents upon which the literature has focused, the bibliometric analysis and integrative framework made it clear that there is little agreement on the relative importance of these antecedents and that certain antecedents, relating to organization (particularly in the form of "formal" organization), and the level of individual agents (including managers) have been neglected.

Our analysis identifies that we still need theoretical development and specific studies in the following areas: (1) an unambiguous definition of absorptive capacity and the impact of different kinds of knowledge on it; (2) the impact of managerial actions and of individual agents and (3) the interdependency of micro-macro processes; (4) the impact of certain organizational antecedents, such as structures and informal networks; (5) the effect of inter-organizational antecedents such as social networks and channels of communication on AC; (6) the exploration of the interactions among intraorganizational and inter-organizational antecedents and their relative importance; (7) a deep understanding of prior related knowledge including organizational memory, temporal issues, stocks and flows; and (8) an evaluation of optimal AC.

These gaps raise opportunities for future research about AC, its antecedents and its impact on outcomes. In the following discussion, we examine these gaps, and our aim is to constructively identify some of the obvious challenges, but also opportunities, for future research. We derive research gaps that 
may guide future research to fully exploit the AC concept in the organization field and to explore fruitful extensions of the concept. We have added to our earlier framework (see Figure 7) additional linkages that help to identify opportunities for future research. Furthermore, to better understand the foundations of AC, we build on the work of Coleman (1990) who states that sometimes it is necessary to study the micro-foundations of a social system in order to better understand it. We identify research opportunities that will explain the social phenomena of AC by explaining the underlying behavior of the antecedents affecting AC.

Insert Figure 7 about here

Clearer definitions of $\mathrm{AC}$ and Construct Boundaries. In spite of the size and richness of the literature on AC, it has yet to converge towards an unambiguous definition. Most contributions to the literature follow the definition of AC à la Cohen and Levinthal (1990) as a firm's ability to "identify, assimilate and exploit knowledge from the environment." In itself the Cohen and Levinthal definition places few constraints on the domain of the construct, which allows many researchers to adapt it to their own needs. While Cohen and Levinthal mostly look at the absorption of technological knowledge, applying AC to market knowledge is entirely consistent with their definition. In this connection, Sidhu, Commandeur and Volberda (2007) make a plea for a three-dimensional search continuum, consisting of supply-side knowledge absorption (new technologies), demand-side knowledge absorption (new markets), and spatial knowledge absorption (new regions). Some authors (e.g., Mowery and Oxley, 1995) define AC as skills relating to tacit technological knowledge. Later authors worked towards sub-dividing the notion of AC, for example, with respect to potential/realized and to the kind of knowledge that is absorbed (e.g., Lim, 2004). Clearly, the nature of this stock and breadth of knowledge is important, and how it is retrieved. In our view, at a minimum, future research needs to be very clear about how AC is being defined, its nature, and what impacts AC.

Research Gap 1a: Research on AC should be explicit about what kind of knowledge is being absorbed.

Research Gap 1b: Research should address the varying nature of knowledge, the knowledge stock and flow of knowledge. 
Managerial Antecedents: The Integration of Micro- and Managerial Foundations. Our bibliometric analysis shows that managerial antecedents are among the most important for studies on AC (see Figure 2). These typically address managerial actions, dominant logic, and human resource mechanisms. Although they define AC as an organization construct, Cohen and Levinthal (1990) also suggest that AC exists on the individual level. In short, AC is a firm-level construct which has a foundation rooted in an understanding of individual cognition, motivation, action and interaction. As Cohen and Levinthal (1990) point out, individual level AC is an important antecedent to organization level AC. Even stronger, the latter is supervenient on the former in the sense that there is no organization level AC without individual level AC. Therefore, the learning behavior of individuals and the choices they make with respect training, education, knowledge sharing, etc., are important foundations of organization level AC.

Thus, the understanding of AC as a dependent variable, absent of a consideration of the level of individuals and their action, may be inherently incomplete. Future research opportunities exist for applying the notion of AC to the individual actor and also to the group and assessing what characteristics of individual cognition, leadership, or motivation influence AC or knowledge flow and utilization. Furthermore, aspects of organizational life such as gatekeepers, experts, job turnover, downsizing, and job rotations, could lend themselves to studies addressing their impact on AC and knowledge.

Research Gap 2: Research on AC should explain the impact of individuals on the AC process.

The Interface between Managerial Antecedents and Intra-Organizational Antecedents. An important characteristic of much strategy and management research in the last two decades is an overriding concern with collective constructs, such as competencies, routines, dynamic capabilities, and so on (Felin and Foss, 2005). Although usually placed on the firm level, such concepts have also been applied to dyadic relations, and even higher levels of aggregation (e.g., Kogut, 2000). The AC construct is no exception to this tendency. The implication is that theories that make use of AC as an independent variable cannot explain crucial (micro-level) links between AC and organization-level outcomes (e.g., differential innovativeness). In some instances, these linkages are crucial. Thus, this identifies a gap in the current research and calls for additional research that integrates the micro-foundations of individual learning and intra-organizational level constructs in hopes that by understanding these components of AC, it will enhance our understanding of AC.

As mentioned, Cohen and Levinthal $(1989,1990)$ define AC as a firm-level construct, specifically as the firm's ability to recognize, assimilate, and apply new knowledge. As such it is descriptive of a property (or set of properties) that exists on the firm level. Collective concepts are wholly legitimate, 
particularly as there are properties that indeed only exist on a collective level. However, an account needs to be made of how the properties described by the collective concept arise from the action and interaction of lower-level entities, such as firm employees, groups or lower level organizational units (Coleman, 1990). In this connection, Cohen and Levinthal (1990: 132) articulate that not only the gatekeeper's absorptive capacity matters, but also that the group as a whole must have some level of relevant background knowledge. In terms of Figure 7, this means explaining the emergence of firm-level AC not only by the direct effects (bold arrows), but also in terms of interactions between managerial, intraorganizational and inter-organizational antecedents (see the dotted arrows).

This is typically not the route that extant literature has taken (with a few exceptions, such as the work of Argote, 1999). Instead, the literature has focused solely on antecedents on the collective level. For example, Zahra and George (2002: 191-192) focus on "external knowledge” and the firm's "past experience" - both cast as collective constructs - as the primary antecedents to AC. In contrast to this aggregate focus, Cohen and Levinthal (1990: 131) did mention the level of the individual and of interaction between individuals as relevant antecedents. As they argue: “An organization's absorptive capacity will depend on the absorptive capacities of its individual members. To this extent, the development of an organization's absorptive capacity will build on the prior investment in the development of its constituent, individual absorptive capacities." In fact, when elucidating the concept of AC, they make continuous reference to psychological theories of individual cognitive structures and the development thereof. ${ }^{3}$

In our view, Cohen and Levinthal and existing research do not establish adequate links between the level of individuals and organization-level AC. That is, they do not truly explain AC in terms of individual level cognition and the interaction between individuals. Rather, the reference to the individual level is mainly designed to make use of theories of individual cognition that are used as metaphors for organization-level AC. For example, it is argued that psychological research suggests that accumulated prior knowledge increases the ability to put new knowledge into memory and the ability to recall and use it, observations that are supposed to "justify and enrich" the notion of organization-level AC. However, current research never truly shows how organization-level AC is related to individual cognition and to the interaction of individuals (including learning from other individuals). In sum, there are opportunities for future research to address the emergence of $\mathrm{AC}$ in a firm. ${ }^{4}$ First, there should be more individual level

\footnotetext{
${ }^{3}$ Moreover, in a complicated multi-level (cf. Dansereau et al., 1999) discussion, they also incorporate the level of business units and their interaction.

${ }^{4}$ To the extent that the emergence or origin of absorptive capacity is discussed at all it is typically in overall terms; for example, “Acquiring absorptive capacity consists of building (1) the firm's ability to access external knowledge, which requires a knowledge-sharing culture, and (2) the firm's ability to transform and implement external knowledge within the company to enhance its core competencies.” (Daghfous, 2004: 21).
} 
foundation for AC. Second, the "bridging laws" that brings us up from one level of analysis to another one should become more transparent in AC research. Suppose we had a good story about the origins of $\mathrm{AC}$ at the individual/managerial level. How then should we aggregate up to the organizational level? The dyadic level? The extent that the dynamics of AC are addressed (i.e., the change, improvement, decay, etc. of AC) and these dynamics are linked to the underlying knowledge-related activities of individuals (i.e., acquiring new knowledge, learning from other individuals in new ways, etc.), we will have a much clearer theory of how organization-level AC arises.

Research Gap 3a: Research on AC should explain the origin of organization-level AC.

Research Gap 3b: Research on AC should clarify how AC existing on different levels of analysis (individual, organizational, dyadic, etc.) are related.

Figure 2 identifies that managerial antecedents have a growing number of citations relating to AC; however, there are opportunities for research, particularly exploring the micro-foundations of AC. For example, such research may focus on the role that key personnel and the turnover play in giving rise to, and changing, AC. This brings issues such as hiring practices, reward systems, and other aspects of human resource management into the picture. For example, Foss, Laursen, and Pedersen (2006) examine the link between the assimilation of knowledge from users and customers and how this is turned into innovation. They find that knowledge-sharing practices - rewards that are linked to knowledge sharing and delegation - are important mediators. The implications of various kinds of training programs also naturally belong here.

Research should also look at specific patterns of communication in organization and structures for knowledge-management such as communities of practice. Opportunities exist to evaluate the impact of communities of practice or the role of technological gatekeepers in discovering the trail of the absorbed knowledge through the organization. Who does it reach, and who not, and why? This focus brings communication channels and network ties into the picture. In other words, a concern with the microfoundations of AC leads naturally to a concern with formal and informal intra-organizational antecedents.

Intra-organizational antecedents. As Lane et al. (2006) point out, antecedents such as organizational structure (e.g., the degree of formalization, the level of decentralization, the use of liaison mechanisms, etc.) have been largely overlooked in the AC literature. With some exceptions, other aspects of "organization" have been similarly neglected, such as human resource mechanisms, reward systems, managerial style, organizational culture, strong and weak network ties, and so on. 
The overall neglect of organizational antecedents goes back to Cohen and Levinthal (1990) who - in spite of very often touching on organizational issues (e.g., organizational gatekeepers, internal communication, departmentalization, etc.) — do not develop a distinct analysis of organization as antecedent to AC. Yet it is clear from their analysis that organizational antecedents must matter. For example, they point out that AC “... refers not only to the acquisition or assimilation of information by an organization, but also to the organization's ability to exploit it. Therefore, an organization's AC does not simply depend on the organization's direct interface with the external environment. It also depends on transfers of knowledge across and within subunits...” (Cohen and Levinthal, 1990: 131) and the capacity for utilizing that knowledge. Future research should address how subunits are defined, which activities they encompass, etc.

Organizational antecedents also include formal organization, such as the allocation of authority and decision rights, the provision of incentives, the grouping of tasks into departments, etc. While recent work has addressed how informal organizations influence knowledge sharing and creation, much less interest has been devoted to formal organizational antecedents of knowledge processes, including the creation of AC. Some research, including Jansen et al. (2005), explores the role of coordination, socialization, and systems capabilities and finds that coordination capabilities (i.e. cross-functional interfaces, participation and job rotation) primarily enhance the potential AC of organizational units, while socialization capabilities (i.e. interdepartmental connectedness and socialization tactics) primarily enhance a unit's realized AC. Moreover, De Boer et al. (1999) and Van den Bosch et al. (1999) show how various organizational forms (e.g. functional, divisional, matrix) differently affect dimensions of AC in terms of efficiency, scope, and flexibility of knowledge integration.

Research Gap 4a: Research on AC should systematically explore how formal organization influences the level, formation, and dynamic nature of AC and the retrieval of prior knowledge.

Recent work by Tsai (2002) may be helpful for launching future research efforts. He investigates the organizational antecedents of knowledge sharing in intra-organizational networks in various parts of the organization. His findings indicate that formal hierarchical structure, in the form of centralization, has a significant negative effect on knowledge sharing. In contrast, informal lateral relations, in the form of social interaction, have a significant positive effect on knowledge sharing. To the extent that increased knowledge sharing implies increased AC (cf. Foss, Laursen, and Pedersen, 2006), Tsai's results provide an initial take on the relative importance of various kinds of organization as antecedents of AC. A gap for future research is linking motivation and explicit monetary incentives to determine if they enhance knowledge sharing. A related research focus is to explore whether formal and informal organization act as substitutes or complements with respect to influencing AC. For example, are rewards for knowledge 
sharing substitutes for social network ties or are they complements? The relative contributions, as well as the interaction of formal and informal organization as antecedents of AC require further research.

Research Gap 4b: Research on AC should analyze the relations (substitutability, complementarity) between different kinds of organization with respect to their impact on AC.

Linkages between Intra-Organizational and Inter-Organizational Antecedents. Within organizations and between organizations knowledge sharing and development are important components of AC. The influence of the social networks and the depth of embeddedness in networks affect the AC in an organization. Often research looks at individuals' networks, and they are assessed and used as beginning points for the organizational level AC. Some research shows that the better interaction there is, the more likely that knowledge will be transferred and assimilated, especially if it is tacit knowledge (Dhanaraj et al., 2004). Reagans and McEvily (2003) and Uzzi (1999) find that it is easier to transfer tacit knowledge when there are strong ties, and it can be done across structural holes. They also show that broad networks can enhance the capability to recognize and assimilate complex ideas. Cross and Cummings (2004) show that centrality in awareness network increases the likelihood of obtaining knowledge that can help to solve novel problems. While the above literature looks at how social ties influence the sharing of knowledge in general, applying these insights in the context of AC would involve looking at how intraorganizational ties influence knowledge assimilated from external sources and afterwards, knowledge disseminated inside the firm. In other words, it involves exploring the informal organizational antecedents to the efficiency of the internal sharing and communication of externally assimilated knowledge (as in Lenox and King, 2004).

Research Gap 5: Research on AC should draw on social network research to clarify how channels of communication implied by networks impact AC.

Integration of Intra-Organizational and Inter-Organizational AC Processes. Another important area for future research is in fully exploring how inter-organizational antecedents interact with intraorganizational antecedents to create and maintain AC (Easterby-Smith et. al., 2008). A neglected part of the original contribution by Cohen and Levinthal is their distinction between "outward-looking” AC and “inward-looking” AC. The former relates to the firm's points of contacts with external sources of knowledge, while the latter refers to "the efficiency of internal communication" (1990: 133). Cohen and Levinthal (idem.) noted that these two aspects of AC may be substitutes: "While both of these organizational components are necessary for effective organizational learning, excessive dominance of by 
one or the other will be dysfunctional. If all actors in the organization share the same specialized language, they will be effective in communicating with one another, but they may not be able to tap into diverse external knowledge sources”.

The Not-Invented-Here syndrome is an extreme manifestation of outward-looking and inwardlooking AC being substitutes. On the other hand, as Cohen and Levinthal mention, both outward- and inward-looking AC would seem to be necessary, as the outward-looking component is not effective without the ability to share internally what has been absorbed from the outside.

Research Gap 6: Research on AC should examine the relationship between intra-organizational and inter-organizational antecedents.

Prior Related Knowledge. Although Cohen and Levinthal (1990) emphasized the importance of prior related knowledge, there is a gap in our understanding of how prior knowledge is recognized, stored, and retrieved. Cohen and Levinthal's (1989) own work involves making use of AC at time t as a crucial antecedent of AC at $\mathrm{t}+1$. Some studies look at organizational stories as a way of communicating prior knowledge (Lyles, 1988). Others, like Lane et. al (2001) for example, are able to use a measure of it from a prior time period, so using longitudinal studies may be one way of capturing prior related knowledge, especially if it is tacit knowledge. Few researchers address the nature of the stock, flow and breadth of knowledge, and how it is stored and retrieved. Or for that matter, what Todorova and Durisin (2007) refer to as the "transformation" of the knowledge structures which assist firms in recognizing new knowledge. We have little understanding of the length of time that knowledge can stay stored in organizational memories or when an organization forgets. There are numerous research opportunities for addressing such issues as the stock and flow of knowledge, the temporal nature of knowledge, and the essence of organizational memory.

Research Gap 7: Research on prior related knowledge should examine the nature of the storage and retrieval of it.

What is Optimum AC? As revealed above, there are strong individual level and organizational dimensions to the AC construct. Individuals cannot automatically be assumed to be docile and contribute towards building AC. Administrative apparatus needs to be deployed to influence employees to undertake the training, form the ties, etc. that assist the building of AC. It only makes sense that some antecedents would have a stronger relationship to AC. Thus, opportunities exist for determining which antecedents among the managerial, intra-organizational, and inter-organizational have the most impact on AC. 
Research Gap 8a: Research on AC should aim to determine which organizational antecedents have the greatest impact.

Furthermore, there is little consideration in the literature of the cost of developing AC, changing it, or in some way taking advantage of an organization's AC. Organizational forgetfulness is not mentioned or linked to individual-level or organizational dimensions that impact optimum AC. All this is costly. Foss and Mahnke (2003) note that the knowledge-based literature at large is strangely innocent of notions of costs (while benefits are usually exalted). In particular, organizational costs, they note, are almost universally ignored. The same is true for the AC literature.

For this reason, the issue of whether there is an optimum level of AC does not appear to be raised in the literature. Thus, maximum AC is implicitly assumed to be desirable, although in the presence of organizational costs of building, maintaining etc. AC, optimum AC is never equal to maximum AC. This suggests the need for research to explore the optimum levels of AC and whether there are ups and downs associated with the level of AC:

Research Gap 8b: Research on AC should not assume that maximum AC = optimum AC; on the contrary, it should identify optimum AC and its determinants, taking into account the (marginal) costs and benefits of building AC.

In this connection, Jansen et al. (2005) note that future studies should investigate what kind of balance between potential and realized AC leads to superior performance. On the basis of their findings in a large multi-unit financial service firm, they expect that organizational units with baseline levels of realized AC and high levels of potential AC will obtain above-normal performance in dynamic markets. By contrast, Zahra \& George's (2002) claim that a high realized-to-potential AC is positively associated with future performance. Externally acquired knowledge undergoes multiple processes before the recipient firm or unit can successfully exploit it. In a successful firm, they argue that realized AC would approach potential AC. However, the study of Jansen et al. (2005) in a large multi-unit financial firm shows somewhat different findings. Organizational units operating in dynamic environments improve their performance by mainly increasing their potential AC. Potential AC provides organizational units with strategic advantages, such as greater flexibility in reconfiguring resources and effective timing of knowledge deployment at lower costs, which are necessary to sustain competitive advantage. Moreover, organizational units may not always be better off by fully realizing their potential AC in dynamic environments. Although realized AC promotes innovation, the resultant products and services may rapidly converge to industry standards and become obsolete relative to current environmental demands (Sorensen and Stuart, 2000). These findings suggest managing levels of potential and realized AC in a 
timely fashion enhances competitive advantage. Moreover, it may be hypothesized that potential and realized absorptive capacities are complements up to a threshold level, at which they become substitutes.

\section{Concluding Discussion}

Although much has been written about absorptive capacity, our article systematically reviews the literature in the field and identifies opportunities for future research and empirical studies. We suggest that there is the need for researchers to build on prior work addressing the nature of AC, prior related knowledge, and on the interactions of the managerial, intra-organizational, and inter-organizational antecedents so that there is an accumulation of knowledge about AC. Even though AC has emerged as one of the central concepts in modern management research, it spans a number of fields in management, such as strategic management, organization theory, international business, etc. This has led to scholars taking many different approaches to AC. It clearly appeals to researchers with different interests and for this reason it may serve as a bridging concept between fields. However, this apparent broad applicability is also the weakness of the AC construct. For this reason the scientific and managerial implications of AC are somewhat unclear (Bacharach, 1989).

In this Perspective paper, we provided a rigorous documentation of the field. The contribution of our work has been to document, on the one hand, the diversity in underlying theories and empirical studies that facilitated the rapid advance of the AC field, but, on the other hand, to analyze its major weaknesses and identify research avenues for further accumulation of knowledge. In particular, based on a bibliometric analysis, we concluded that intra-organizational antecedents, organizational innovation and realized AC have been comparatively under-researched in the extant literature on AC. Similarly, we also found that the role of individuals and their interaction has been only tangentially included in research on AC. In order to address these shortcomings, we developed an integrative framework of AC that identifies the underlying dimensions, its multi-level antecedents, its outcomes and the contextual factors that affect AC. From this, we developed various avenues for further research: (1) conceptual work on the definition of absorptive capacity and its construct boundaries; (2) empirical research on the impact of managerial actions and of individual agents and (3) theoretical as well empirical research efforts on the interdependency of micro-macro processes; (4) studies on the impact of certain intra-organizational antecedents, such as structures and informal networks; (5) better understanding of how interorganizational networks influence AC; (6) empirical explorations of the interactions among and relative importance of intra-organizational and inter-organizational antecedents; (7) deep understanding of prior 
related knowledge including organizational memory, temporal issues, stocks and flows; and (8) evaluation of optimal AC.

In summary, the theoretical foundation of AC is lacking in some crucial dimensions and therefore, there are many promising areas for future research. One critical area is that our understanding of the micro-foundations of AC needs further development. That is, we do not understand how AC arises, exerts its influence on innovation and competitive advantage, and is subsequently transformed in terms of individual action and interaction that is embedded in an organizational context. While there is much empirical evidence that prior related firm-level knowledge is an important antecedent to AC, such knowledge does not exert its influence on AC directly. It works by influencing what individuals know and can do, and by influencing their interaction. We also do not fully understand the interaction of intra- and inter-organizational antecedents on AC-we know these cannot be separated but which aspects are most important? Furthermore, we don not know whether AC becomes optimal, out-of-date or ineffective. Currently, this "deep structure” of AC is missing from the literature. We have suggested a number of ways in which research may overcome these lacunae.

\section{References}

Adner, R., C.E. Helfat. 2003. Corporate effects and dynamic managerial capabilities. Strategic Management Journal. 24 1011-1025.

Ahuja, G. 2000. The duality of collaboration: Inducements and opportunities in the formation of interfirm linkages. Strategic Management Journal. 21(3) 317-343.

Ahuja, G, C.M. Lampert. 2001. Entrepreneurship in the large corporation: A longitudinal study of how established firms create breakthrough inventions. Strategic Management Journal. 22: 521-543.

Andersen, T.J., N.J. Foss. 2005. Strategic opportunity and economic performance in multinational enterprises: The role and effects of information and communication technology. Journal of International Management. 11 293-310.

Argote, L. 1999. Organizational Learning: Creating, Retaining and Transferring Knowledge. Kluwer, Boston.

Argote, L., B. McEvily, R. Reagans. 2003. Managing Knowledge in Organizations: An Integrative Framework and Review of Emerging Themes. Management Science. 49 (4) 571-582.

Bacharach, S.B. 1989. Organizational theories: Some criteria for evaluation. Academy of Management Review. 14 496-515.

Bettis, R.A., C.K. Prahalad. 1995. The dominant logic: Retrospective and extension. Strategic Management Journal. 16 5-14.

Calori, R., G. Johnson, P. Sarnin. 1994. CEOs' cognitive maps and the scope of the organization. Strategic Management Journal. 15 437-457.

Chesbrough, H. 2003. Open innovation. Harvard University Press, Cambridge. 
Cockburn, I.M., R.M. Henderson. 1998. Absorptive capacity, coauthoring bahaviour, and the organization of research in drug discovery. Journal of Industrial Economics. 46 157-182.

Cohen, W.M., D. Levinthal. 1989. Innovation and learning: The two faces of R\&D. The Economic Journal. 99 569-596.

Cohen, W.M., D. Levinthal. 1990. Absorptive capacity: A new perspective on learning and innovation. Administrative Science Quarterly. 35 128-152.

Cohen, W.M., D. Levinthal. 1994. Fortune favors the prepared firm. Management Science. 40(2) 227251.

Cohen, W.M., D.A. Levinthal. 1997. Fortune favors the prepared firm - reply. Management Science. 43(10) 1463-1468.

Coleman, J. 1990. Foundations of Social Theory. University of Chicago Press, Chicago.

Cross, R., J.N. Cummings. 2004. Tie and network correlates of individual performance in knowledge intensive network. Academy of Management Journal. 47(6) 928-937.

Czarnitzki, D., K. Kraft. 2004. An empirical test of the asymmetric models on innovative activity: Who invests more into R\&D, the incumbent or the challenger? Journal of Economic Behavior and Organization. 54(2) 153-173.

Daghfous, A. 2004. Absorptive capacity and the implementation of knowledge-intensive best practices. S.A.M. Advanced Management Journal. 69(2) 21-27.

Dansereau, F., F.J. Yammarino, J.C. Kohles. 1999. Multiple levels of analysis from a longitudinal perspective: Some implications for theory building. Academy of Management Review. 24 346- 357.

David, P.A. 1975. Technical choice innovation and economic growth. Cambridge University Press, Cambridge.

De Boer, M., F.A.J. Van den Bosch, H.W. Volberda. 1999. Managing organizational knowledge integration in the emerging multimedia complex. Journal of Management Studies. 36 379-398.

Dhanaraj, C., M. Lyles, K. Steensma, L. Tihanyi. 2004. The dynamics of relational embeddedness: Tacit and explicit learning in international joint ventures. Journal of International Business Studies. 35(5) 428-443.

Dijksterhuis, M.S., F.A.J. Van den Bosch, H.W. Volberda. 1999. Where do new organizational forms come from? Management logics as a source of coevolution. Organization Science. 10 569-582.

Easterby-Smith, M., M.A. Lyles, E. Tsang. 2008. Inter-organizational knowledge transfer: current themes and future prospects. Journal of Management Studies. 45(4) 661-674.

Feinberg, S.E., A.K. Gupta. 2004. Knowledge spillovers and the assignment of R\&D responsibilities to foreign subsidiaries. Strategic Management Journal. 25 823-845.

Felin, T., N. Foss. 2005. Strategic organization: a field in search of micro-foundations. Strategic Organization. 3(4): 441-455.

Fiol, C.M., M.A. Lyles. 1985. Organizational learning. Academy of Management Review. 10 803-813.

Floyd, S.W., P.J. Lane. 2000. Strategizing throughout the organization: Managing role conflict in strategic renewal. Academy of Management Review. 25 154-177.

Foss, N.J. 2006. Knowledge and organization in the theory of the multinational enterprise. Journal of Management and Governanace. 10 3-20. 
Foss, N., V. Mahnke. 2003. Knowledge management: What can organizational economics contribute? M. Easterby-Smith, M. Lyles, eds. Handbook of Organizational Learning and Knowledge Management. Blackwell Publisher, 78-103.

Foss, N.J., T. Pedersen. 2004. Organizing knowledge processes in the multinational corporation: An introduction. Journal of International Business Studies. 35 340-349.

Foss, N.J., K. Laursen, T. Pedersen. 2006. Organizing to gain from interaction with consumers: The role of organizational practices for absorptive and innovative capacity. Working Paper.

Geroski, P., S. Machin, J. Van Reenen. 1993. The profitability of innovating firms. The RAND Journal of Economics. 24(2) 198-211.

Garud, R., P.R. Nayyar. 1994. Transformative capacity: Continual structuring by intertemporal knowledge transfer. Strategic Management Journal. 15 365-385.

Grant, R.M. 1996a. Toward a knowledge-based theory of the firm. Strategic Management Journal. 17 109-122.

Grant, R.M. 1996b. Prospering in dynamically-competitive environments: Organizational capability as knowledge integration. Organization Science. 7 375-387.

Gupta, A.K., V. Govindarajan. 2000. Knowledge flows within the multinational corporation. Strategic Management Journal. 21 473-496.

Hall, B. 2000. Innovation and market value. R. Barro, G. Mason, M. O'Mahony, eds. Productivity, innovation and economic performance. Cambridge University Press, Cambridge.

Huygens, M., C. Baden-Fuller, F.A.J. Van den Bosch, H.W. Volberda. 2001. Co-evolution of firm capabilities and industry competition: Investigating the music industry, 1877-1997. Organization Studies. 22 971-1011.

Jansen, J.J.P., F.A.J. Van den Bosch, H.W. Volberda. 2005. Managing potential and realized absorptive capacity: How do organizational antecedents matter? Academy of Management Journal. 48 9991015.

Kedia, B.L., R.S. Bhagat. 1988. Cultural constraints on transfer of technology across nations: Implications for research in international and comparative advantage. Academy of Management Review. 13 559-571.

Kogut, B., U. Zander. 1992. Knowledge of the firm, combinative capabilities, and the replication of technology. Organization Science. 3 383-397.

Kogut, B. 2000. The network as knowledge: generative rules and the emergence of structure. Strategic Management Journal. 21(3) 405-425.

Koza, M. P., A.Y. Lewin. 1999. The coevolution of network alliances: A longitudinal analysis of an international professional service network. Organization Science. 10(5) 638-653.

Lane, P.J., M. Lubatkin. 1998. Relative absorptive capacity and inter-organizational learning. Strategic Management Journal. 19 461-477.

Lane, P.J., B.R. Koka, S. Pathak. 2006. The reification of absorptive capacity: A critical review and rejuvenation of the construct. Academy of Management Review. 31(4) 833-863.

Lane, P.J., J.E. Salk, M.A. Lyles. 2001. Absorptive capacity, learning, and performance in international joint ventures. Strategic Management Journal. 22 1139-1161.

Laursen, K., A.J. Salter. 2006. Open for innovation: The role of openness in explaining innovative performance among UK manufacturing firms. Strategic Management Journal. 27 131-150. 
Lenox, M., A. King. 2004. Prospects for developing absorptive capacity through internal information provision. Strategic Management Journal. 25 331-345.

Levitt, B., J.G. March. 1988. Organizational learning. Annual Review of Sociology. 14 319-340.

Lewin, A.Y., C.P. Long, T.N. Carroll. 1999. The coevolution of new organizational forms. Organization Science. 10 535-550.

Lewin, A.Y., H.W. Volberda. 1999. Prolegomena on coevolution: A framework for research on strategy and new organizational forms. Organization Science. 10 519-534.

Lim, K. 2004. The many faces of absorptive capacity: Spillovers of copper interconnect technology for semiconductor technology. Working paper.

Loasby, B.J. 1976. Choice, Complexity and Ignorance. Cambridge University Press, Cambridge.

Lyles, M.A. 1988. Learning among joint venture sophisticated firms. Management International Review, 28 85-98.

Lyles, M.A., C.R. Schwenk. 1992. Top management, strategy and organizational knowledge structures. Journal of Management Studies. 29 155-174.

Lyles, M.A., J.E. Salk. 1996. Knowledge acquisition from foreign partners in international joint ventures. Journal of International Business Studies. 27(5) 877-904.

Malhotra, A., S. Gosain, O.A. El Sawy. 2005. Absorptive capacity configurations in supply chains: Gearing for partner-enabled market knowledge creation. MIS Quarterly. 29 145-187.

Matusik, S.F., M.B. Heeley. 2005. Absorptive capacity in the software industry: Identifying dimensions that affect knowledge and knowledge creation activities. Journal of Management. 31 549-572.

McEvily, S.K., B. Chakravarthy. 2002. The persistence of knowledge-based advantage: an empirical test for product performance and technological knowledge. Strategic Management Journal. 23(4) 285305.

Minbaeva, D., T. Pedersen, I. Björkman, C.F. Fey, H.J. Park. 2003. MNC knowledge transfer, subsidiary absorptive capacity, and HRM. Journal of International Business Studies. 34 586-599.

Mom, T.J.M, F.A.J. Van den Bosch, H.W. Volberda. 2007. Investigating Manager's Exploration and Exploitation Activities: The Influence of Top-Down, Bottom-Up, and Horizontal Knowledge Inflows, Journal of Management Studies. 44(6): 910-931.

Mowery, D.C., J.E. Oxley. 1995. Inward technology - transfer and competitiveness - the role of national innovation systems. Cambridge Journal of Economics. 19(1) 67-93.

Mowery, D.C., J.E. Oxley, B.S. Silverman. 1996. Strategic alliances and interfirm knowledge transfer. Strategic Management Journal. 17 77-91.

Nelson, R.R., S.G. Winter. 1982. An evolutionary theory of economic change. Mass: Harvard University Press, Cambridge.

Nicholls-Nixon, C. 1993. Absorptive capacity and technological sourcing: Implications for the responsiveness of established firms. Unpublished doctoral dissertation. Purdue University.

Nonaka, I., 1994. A dynamic theory of organizational knowledge creation. Organization Science. 5 1437.

Noyons, E.C.M., A.F.J. Van Raan. 1998a. Monitoring scientific developments from a dynamic perspective: Self-organized structuring to map neural network research. Journal of the American Society for Information Science. 49(1) 68-81. 
Noyons, E.C.M., A.F.J. Van Raan. 1998b. Advanced mapping of science and technology. Scientometrics. 41 61-67.

Noyons, E.C.M., M. Luwel, H.F. Moed. 1999. Combining mapping and citation analysis for evaluative bibliometric purposes. Journal of American Society for Information Science. 50(2) 115-131.

Pennings, J.M., F. Harianto. 1992. The diffusion of technological innovation in the commercial banking industry. Strategic Management Journal. 13 29-46.

Pisano, G.P. 1994. Knowledge, integration, and the locus of learning - an empirical - analysis of processdevelopment. Strategic Management Journal. 15(Special Issue) 85-100.

Powell, W.W., K.W. Koput, L. Smith-Doerr. 1996. Interorganizational collaboration and the locus of innovation: Networks of learning in biotechnology. Administrative Science Quarterly. 41 116-145.

Prahalad, C.K., R.A. Bettis. 1986. The dominant logic. A new linkage between diversity and performance. Strategic Management Journal. 7 485-501.

Reagans, R., B. McEvily. 2003. Network structure and knowledge transfer: The effects of cohesion and range. Administrative Science Quarterly. 48 240-267.

Roberts, J. 2004. The Modern Firm. Oxford University Press, Oxford.

Rosenkopf, L., P. Almeida. 2003. Overcoming local search through alliances and mobility. Management Science. 49 751-766.

Shane, S. 2000. Prior knowledge and the discovery of entrepreneurial opportunities. Organization Science. 11 448-469.

Sanchez, R. ed. 2001. Knowledge Management and Organizational Competence. Oxford University Press, Oxford.

Scott, W.R. 1987. Organizations - Rational, natural and Open Systems. $2^{\text {nd }}$ ed. Prentice Hall, Englewood Cliffs, NJ.

Sorensen, J.B., T.E. Stuart. 2000. Aging, obsolescence, and organizational innovation. Administrative Science Quarterly, 47 81-112.

Shenkar, O., J. Li. 1999. Knowledge search in international cooperative ventures. Organization Science. 10(2) 134-143.

Sidhu, J., H. Commandeur, H.W. Volberda. 2007. The Multifaceted Nature of Exploration and Exploitation: Value of Supply, Demand, and Spatial Search for Innovation. Organization Science, 18 1-19.

Starbuck, W.H. 1992. Learning by knowledge-intensive firms. Journal of Management Studies. 29 713740.

Stiglitz, J.E. 1987. Learning to learn, localized learning and technological progress. P. Dasgupta, P. Stoneman, eds. Economic Policy and Technological Performance. Cambridge University Press, Cambridge.

Stock, G.N., N.P. Greis, W.A. Fischer. 2001. Absorptive capacity and new product development. The Journal of High Technology Management Research. 12 77-91.

Stuart, T.E. 1998. Network positions and propensities to collaborate: An investigation of strategic alliance formation in a high-technology industry. Administrative Science Quarterly. 43 668-698.

Teece, D., G. Pisano, A. Shuen. 1997. Dynamic capabilities and strategic management. Strategic Management Journal. 18(7) 509-533. 
Todorova, G., Durisin, B. 2007. Absorptive capacity: valuing a reconceptualization. Academy of Management Review. 32(3): 774-786.

Tsai, W. 2002. Social structure of "coopetition" within a multiunit organization: Coordination, competition, and intraorganizational knowledge sharing. Organization Science. 13(2) 179-190.

Tsai, W. 2001. Knowledge transfer in intraorganizational networks: Effects of network position and absorptive capacity on business unit innovation and performance. Academy of Management Journal. 44 996-1004.

Uzzi, B. 1999. Embeddedness in the making of financial capital: How social relations and networks benefit firms seeking financing. American Sociological Review. 64 481-505.

Van den Bosch, F.A.J., R. Van Wijk. 2001. Creation of managerial capabilities through managerial knowledge integration: A competence-based perspective. R. Sanchez, eds. Knowledge Management and Organizational Competence. Oxford University Press, Oxford, 159-176.

Van den Bosch, F.A.J., R. Van Wijk, H.W. Volberda. 2003. Absorptive capacity: Antecedents, models and outcomes. M. Easterby-Smith, M.A. Lyles, eds. The Blackwell Handbook of Organizational Learning and Knowledge Management. Blackwell, Malden, 278-301.

Van den Bosch, F.A.J., H.W. Volberda, M. De Boer. 1999. Coevolution of firm absorptive capacity and knowledge environment: Organizational forms and combinative capabilities. Organization Science. 10 551-568.

Van Wijk, R., F.A.J. Van den Bosch, H.W. Volberda. 2003. Knowledge and networks. M. EasterbySmith, M.A. Lyles, eds. The Blackwell Handbook of Organizational Learning and Knowledge Management. Blackwell, Malden, 428-453.

Volberda, H.W. 1996. Toward the Flexible Firm: How To Remain Vital in Hypercompetitive Environments, Organization Science, 7 (4): 359-387.

Volberda, H.W. 1998. Building the Flexible Firm: How to Remain Competitive. Oxford University Press, Oxford.

Volberda, H.W., C. Baden-Fuller, F.A.J. Van den Bosch. 2001. Mastering strategic renewal: Mobilising renewal journeys in multi-unit firms. Long Range Planning. 34 159-178.

Volberda, H.W., A.Y. Lewin. 2003. Co-evolutionary dynamics within and between firms: From evolution to co-evolution. Journal of Management Studies. 40 2111-2136.

Whittington, R., A. Pettigrew, S. Peck, E. Fenton, M. Conyon. 1999. Change and complementarities in the New Competitive Landscape: A European Panel Study 1992-1996. Organization Science 10 583-600.

Zahra, S.A., G. George. 2002. Absorptive capacity: A review, reconceptualization, and extension. Academy of Management Review. 27 185-203. 
TABLE 1: Theories informing Absorptive Capacity: Contributions, constructs, and implications

$\begin{array}{ll}\text { Theories } & \text { Main contributions } \\ \text { Learning } & \text { Fiol \& Lyles (1985) } \\ & \text { Levitt \& March (1988) } \\ & \text { Cohen \& Levinthal (1989, 1990) } \\ & \text { Lyles \& Salk (1996) } \\ & \text { Lane \& Lubatkin (1998) } \\ & \text { Lane, Salk \& Lyles (2001) } \\ & \text { Reagans \& McEvily (2003) } \\ & \text { Dhanaraj et. al. (2004) } \\ & \text { Lane et al. (2006) } \\ & \\ & \text { Kedia \& Bhagat (1988) } \\ & \text { Cohen \& Levinthal (1989, 1990) } \\ & \text { Cockburn \& Henderson (1998) } \\ & \text { Feinberg and Gupta (2004) } \\ & \\ \text { Innovation } & \\ & \\ \text { Knowledge-based } & \text { Kogut \& Zander (1992) } \\ & \text { Starbuck (1992) } \\ & \text { Garud \& Nayyar (1994) } \\ & \text { Bettis \& Prahalad (1986, 1995) } \\ & \text { Lyles \& Schwenk (1992) } \\ \text { Calori et al. (1994) } \\ \text { Managerial } \\ \text { Dijksterhuis et al. (1999) } \\ \text { Van den Bosch \& Van Wijk } \\ \text { (2001) } \\ \text { Sanchez (2001) } \\ \text { Lenox and King (2004) } \\ \text { Minbaeva et al. (2003) } \\ \\ \end{array}$

\section{AC-related constructs}

Organizational learning is based on direct experience and routines, history-dependent and target-oriented, and

influenced by contextual factors.

Prior related knowledge is the most important antecedent of AC.

Relative AC is more relevant for interorganizational learning than R\&D-based AC.

The influence of technological opportunity and appropriability regimes on innovation is mediated by AC.

R\&D and AC interact to increase a firm's knowledge base and innovation.

There is more to AC than just R\&D, several (inter-) organizational characteristics play a key role.

Complexity tends to be resolved by a dominant logic. More diversity in a firm's activities increases the comprehensiveness and complexity of the CEO's mental map of the environment.

Management logics greatly influence a firm's actions in the competitive landscape, as well as the emergence of new organizational forms.

Providing information by managers as well as individuals' abilities and motivations enhance AC.

Combinative capabilities play a key role in leveraging organizational knowledge.

The knowledge characteristics of the environment

\section{Implications}

- AC consists of three dimensions: recognition, assimilation, and exploitation.

- (Inter)Organizational context matters for AC.

- Levels of analysis: individuals, organizations, dyads, and networks.

- AC influences innovative performance.

- $\quad$ AC as by-product of R\&D.

- Cultural differences between countries affect AC.

- (Inter)Organizational context matters for AC.

- Management logics, through organizational forms, influence absorptive capacity, especially in complex environments.

- Managers can develop AC by directly providing information.

- Individuals' abilities as well as their motivations enhance AC.

- High AC increases the amount and productivity of knowledge.

- Combinative capabilities, 
Grant (1996a, 1996b)

Van den Bosch et al. (1999)

Van Wijk et al. (2003)

Foss and Pedersen (2004)

Andersen and Foss (2005)

Malhotra et al. (2005)

Matusik and Heeley (2005)

Dynamic

capabilities

Cohen \& Levinthal (1994)

Grant (1996b)

Van den Bosch et al. (1999)

Floyd and Lane (2000)

Zahra \& George (2002)

Jansen et al. (2005)

Co-evolution

Cohen \& Levinthal (1994, 1997)

Koza \& Lewin (1999)

Lewin et al. (1999)

Lewin \& Volberda (1999)

Van den Bosch et al. (1999)

Huygens et al. (2001)

Volberda \& Lewin (2003) influence the characteristics of the knowledge absorption by the firm.

Organizational form determines the characteristics of

AC.

Network properties influence the level of AC.

$\mathrm{AC}$ is a capability and thus requires investments.

AC, being itself a high-level capability, is also the result of lower-level organizational or combinative capabilities. Potential and realized AC (PAC and RAC) can be broken down into knowledge acquisition, assimilation, transformation, and exploitation capabilities.

Macro-coevolutionary effects: Knowledge environments co-evolve with the emergence of organizational forms and combinative capabilities that are suitable for absorbing knowledge

Micro-coevolutionary effects: Increasing levels of AC lead to more readily accumulating additional knowledge in subsequent periods. Higher levels of AC raise the aspiration level and increase the level of exploration adaptation. organizational form, and knowledge characteristics all influence the firm's AC.

- $\mathrm{AC}$ is particularly relevant when knowledge is shared.

- AC is a high-level capability, supported by other capabilities

- $\quad$ PAC consists of knowledge acquisition and assimilation capabilities and is increased by coordination capabilities

- $\quad$ RAC consists of knowledge transformation and exploitation capabilities and is increased by systems and socialization capabilities

- $\quad \mathrm{AC}$ enables or restricts firm adaptation

- AC co-evolves with the knowledge environment.

- Levels and direction of AC are shaped by the joint effect of managerial actions and developments in the knowledge environment

FIGURE 1: Bibliometric Map of the Field of Absorptive Capacity. 


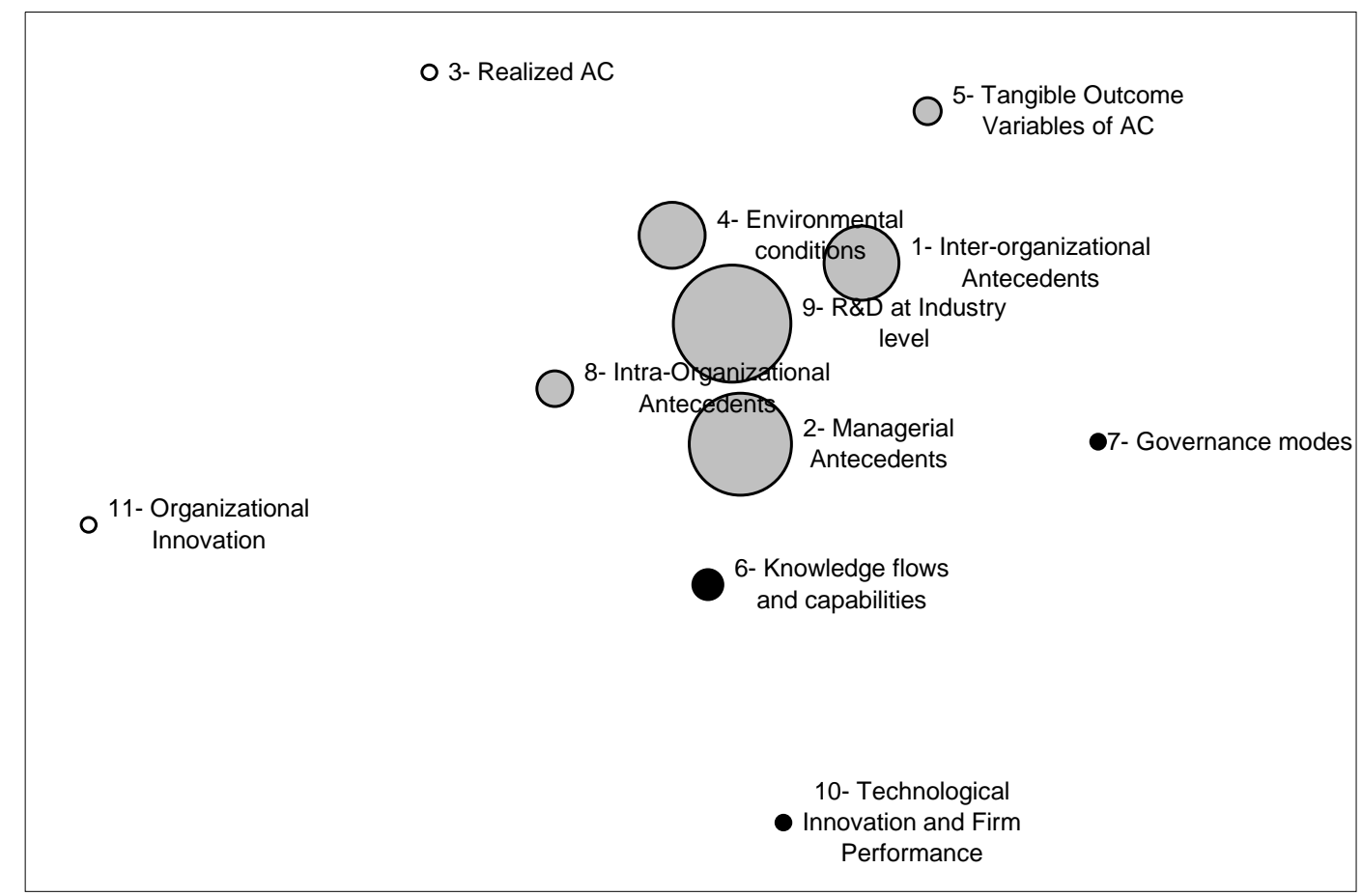

FIGURE 2: Growth in Numbers of Publications (Moving Averages) in the three Antecedents subfields 


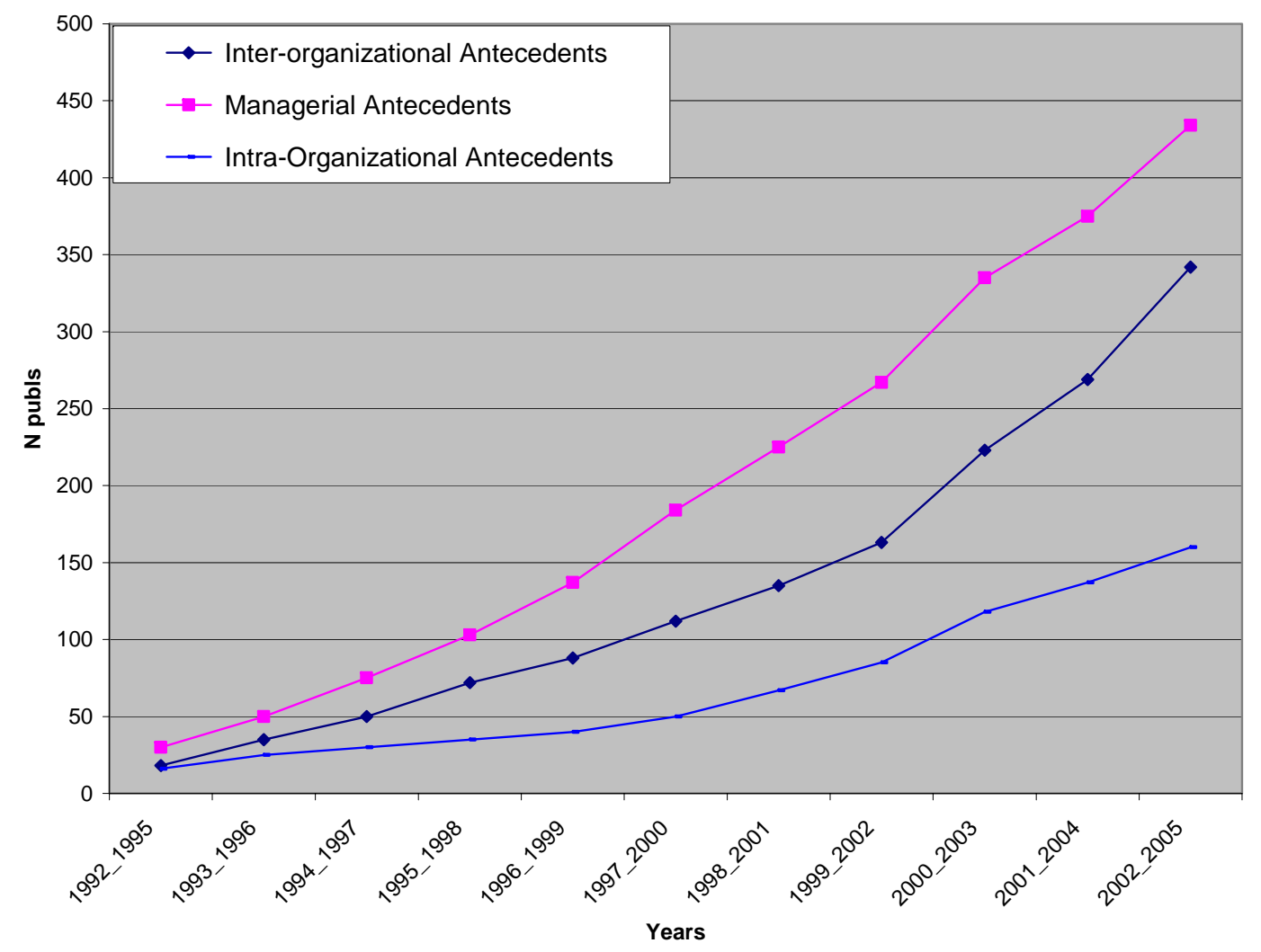

FIGURE 3: Growth in Numbers of Publications (Moving Averages) in 
Two Sub-Domains (Fast and Slow) in the Field of Absorptive Capacity

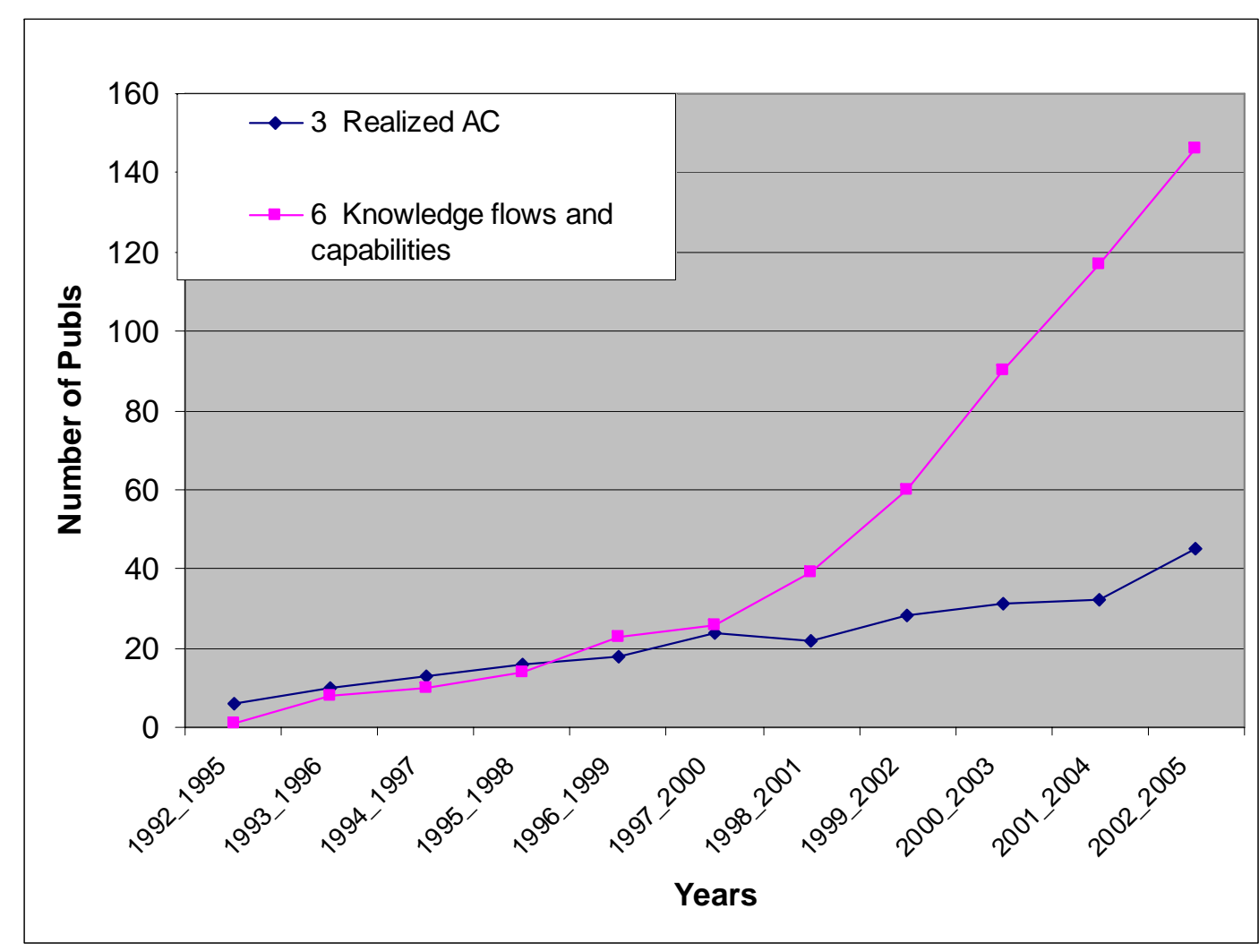


FIGURE 4: Growth in Numbers of Publications (Moving Averages) in

Two Sub-Domains (Fast and Slow) in the Field of Absorptive Capacity

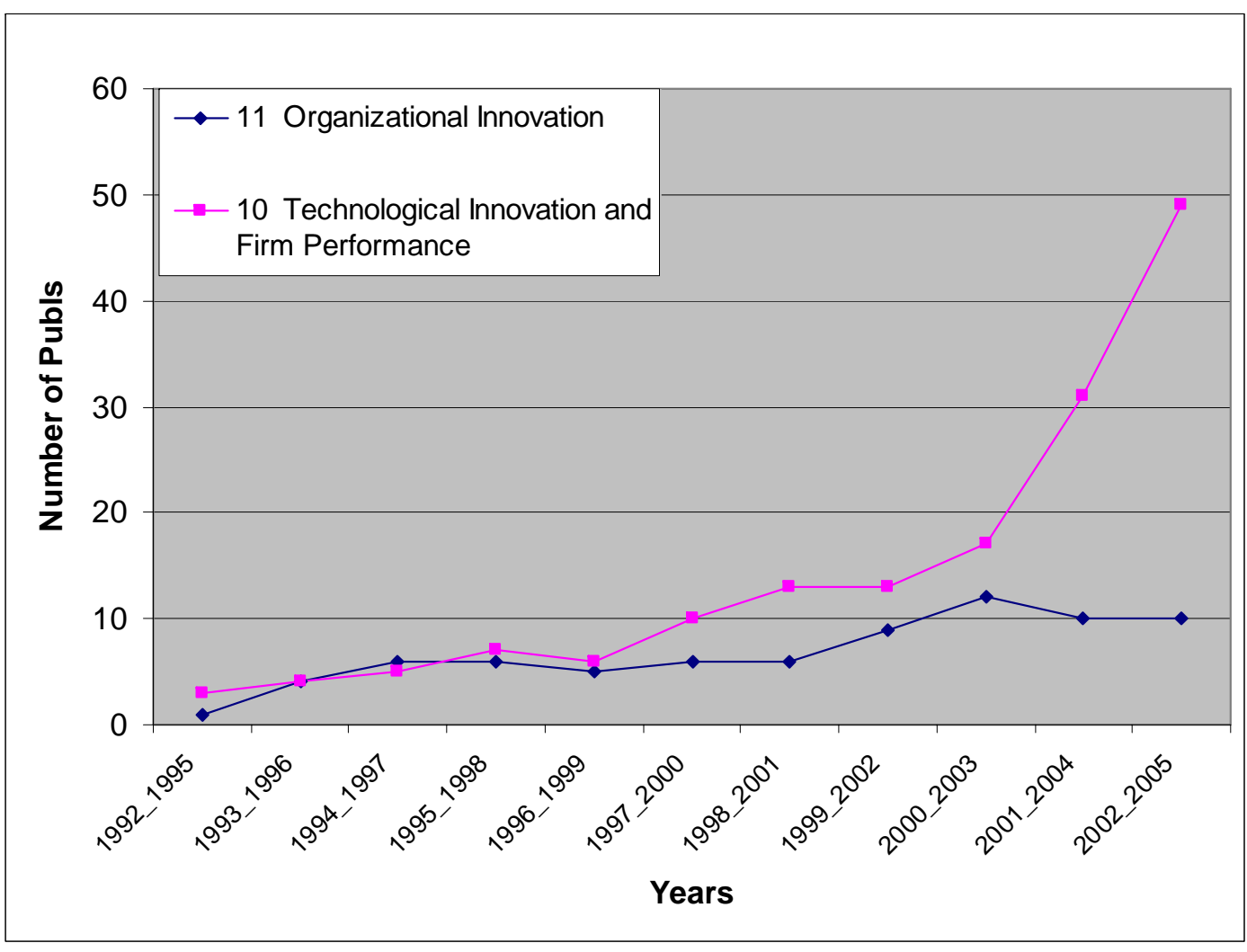


FIGURE 5: Growth in Numbers of Publications (Moving Averages) in Two Sub-Domains in the Field of Absorptive Capacity

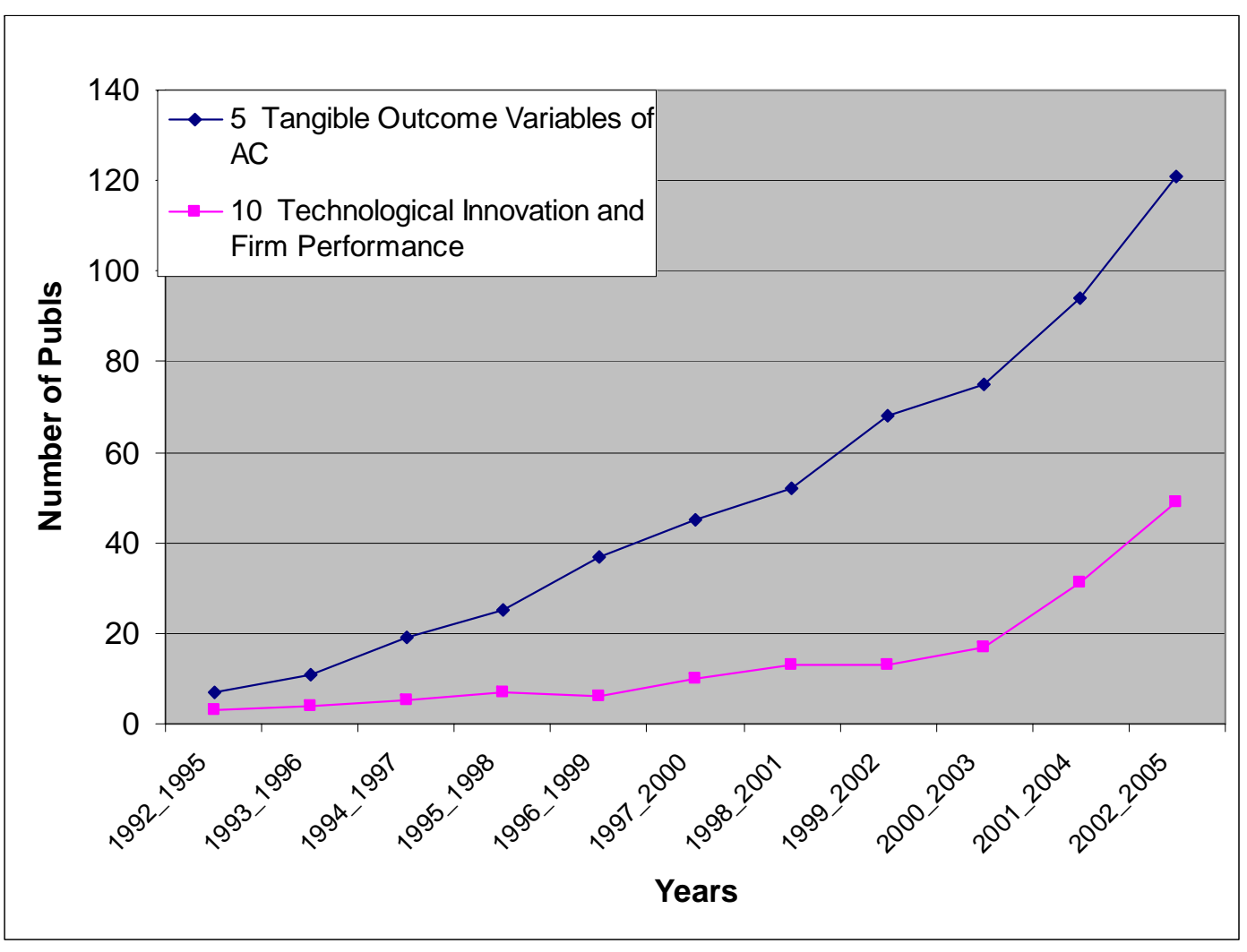




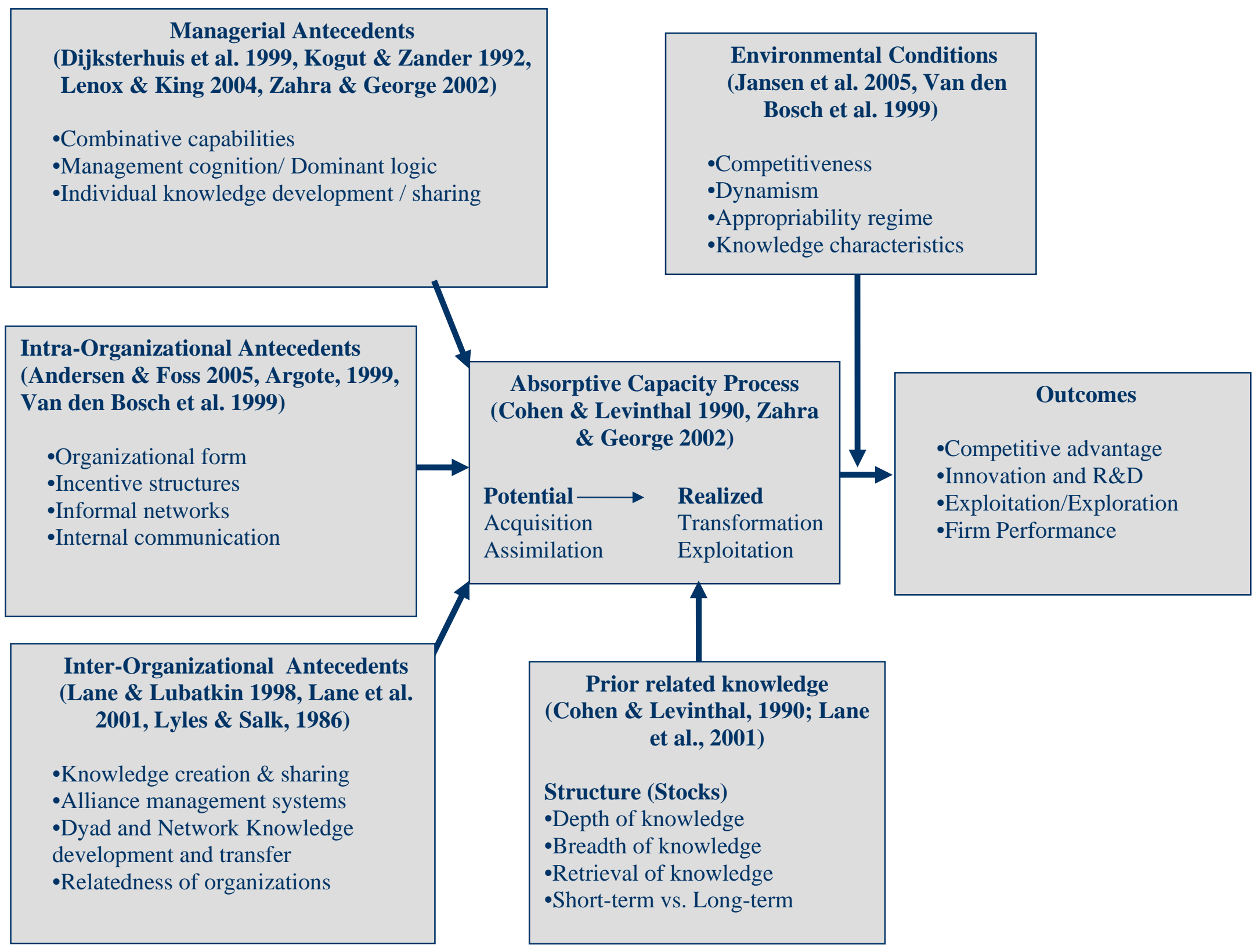

FIGURE 6: AN INTEGRATIVE FRAMEWORK OF ABSORPTIVE CAPACITY 


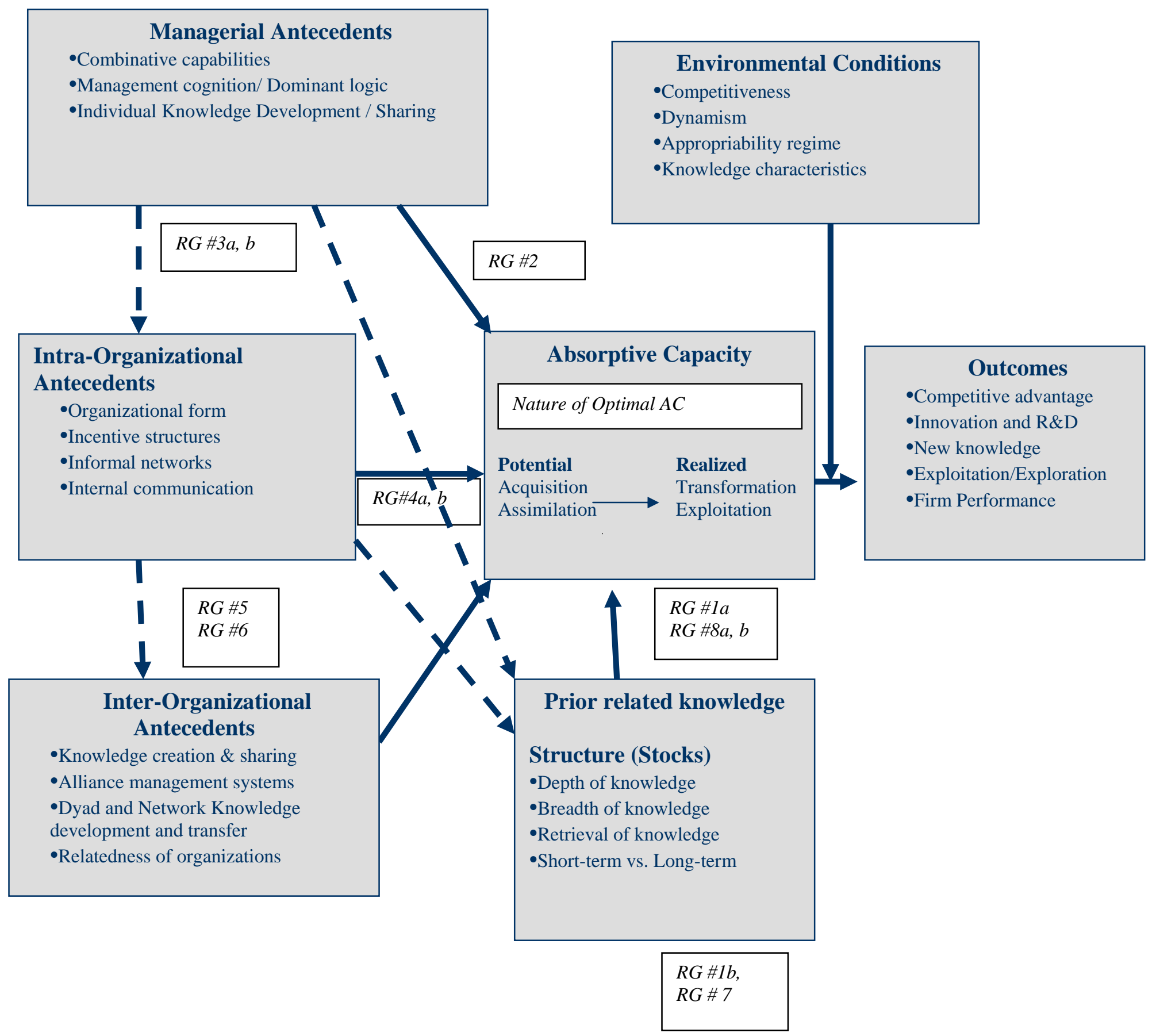




\section{SMG - Working Papers \\ www.cbs.dk/smg \\ 2003}

2003-1: Nicolai J. Foss, Kenneth Husted, Snejina Michailova, and Torben Pedersen: Governing Knowledge Processes: Theoretical Foundations and Research Opportunities.

2003-2: Yves Doz, Nicolai J. Foss, Stefanie Lenway, Marjorie Lyles, Silvia Massini, Thomas P. Murtha and Torben Pedersen: Future Frontiers in International Management Research: Innovation, Knowledge Creation, and Change in Multinational Companies.

2003-3: Snejina Michailova and Kate Hutchings: The Impact of In-Groups and OutGroups on Knowledge Sharing in Russia and China CKG Working Paper.

2003-4: Nicolai J. Foss and Torben Pedersen: The MNC as a Knowledge Structure: The Roles of Knowledge Sources and Organizational Instruments in MNC Knowledge Management CKG Working Paper.

2003-5: Kirsten Foss, Nicolai J. Foss and Xosé H. Vázquez-Vicente: “Tying the Manager's Hands": How Firms Can Make Credible Commitments That Make Opportunistic Managerial Intervention Less Likely CKG Working Paper.

2003-6: Marjorie Lyles, Torben Pedersen and Bent Petersen: Knowledge Gaps: The Case of Knowledge about Foreign Entry.

2003-7: Kirsten Foss and Nicolai J. Foss: The Limits to Designed Orders: Authority under "Distributed Knowledge" CKG Working Paper.

2003-8: Jens Gammelgaard and Torben Pedersen: Internal versus External Knowledge Sourcing of Subsidiaries - An Organizational Trade-Off.

2003-9: Kate Hutchings and Snejina Michailova: Facilitating Knowledge Sharing in Russian and Chinese Subsidiaries: The Importance of Groups and Personal Networks Accepted for publication in Journal of Knowledge Management.

2003-10: Volker Mahnke, Torben Pedersen and Markus Verzin: The Impact of Knowledge Management on MNC Subsidiary Performance: the Role of Absorptive Capacity CKG Working Paper.

2003-11: Tomas Hellström and Kenneth Husted: Mapping Knowledge and Intellectual Capital in Academic Environments: A Focus Group Study Accepted for publication in Journal of Intellectual Capital CKG Working Paper.

2003-12: Nicolai J Foss: Cognition and Motivation in the Theory of the Firm: Interaction or "Never the Twain Shall Meet"? Accepted for publication in Journal des Economistes et des Etudes Humaines CKG Working Paper.

2003-13: Dana Minbaeva and Snejina Michailova: Knowledge Transfer and Expatriation Practices in MNCs: The Role of Disseminative Capacity.

2003-14: Christian Vintergaard and Kenneth Husted: Enhancing Selective Capacity Through Venture Bases. 


\section{4}

2004-1: Nicolai J. Foss: Knowledge and Organization in the Theory of the Multinational Corporation: Some Foundational Issues

2004-2: Dana B. Minbaeva: HRM Practices and MNC Knowledge Transfer

2004-3: Bo Bernhard Nielsen and Snejina Michailova: Toward a Phase-Model of Global Knowledge Management Systems in Multinational Corporations

2004-4: Kirsten Foss \& Nicolai J Foss: The Next Step in the Evolution of the RBV: Integration with Transaction Cost Economics

2004-5: Teppo Felin \& Nicolai J. Foss: Methodological Individualism and the Organizational Capabilities Approach

2004-6: Jens Gammelgaard, Kenneth Husted, Snejina Michailova: Knowledge-sharing Behavior and Post-acquisition Integration Failure

2004-7: Jens Gammelgaard: Multinational Exploration of Acquired R\&D Activities

2004-8: Christoph Dörrenbächer \& Jens Gammelgaard: Subsidiary Upgrading? Strategic Inertia in the Development of German-owned Subsidiaries in Hungary

2004-9: Kirsten Foss \& Nicolai J. Foss: Resources and Transaction Costs: How the Economics of Property Rights Furthers the Resource-based View

2004-10: Jens Gammelgaard \& Thomas Ritter: The Knowledge Retrieval Matrix: Codification and Personification as Separate Strategies

2004-11: Nicolai J. Foss \& Peter G. Klein: Entrepreneurship and the Economic Theory of the Firm: Any Gains from Trade?

2004-12: Akshey Gupta \& Snejina Michailova: Knowledge Sharing in Knowledge-Intensive Firms: Opportunities and Limitations of Knowledge Codification

2004-13: Snejina Michailova \& Kate Hutchings: Knowledge Sharing and National Culture: A Comparison Between China and Russia

\section{5}

2005-1: Keld Laursen \& Ammon Salter: My Precious - The Role of Appropriability Strategies in Shaping Innovative Performance

2005-2: Nicolai J. Foss \& Peter G. Klein: The Theory of the Firm and Its Critics: A Stocktaking and Assessment

2005-3: Lars Bo Jeppesen \& Lars Frederiksen: Why Firm-Established User Communities Work for Innovation: The Personal Attributes of Innovative Users in the Case of Computer-Controlled Music

2005-4: Dana B. Minbaeva: Negative Impact of HRM Complementarity on Knowledge Transfer in MNCs

2005-5: Kirsten Foss, Nicolai J. Foss, Peter G. Klein \& Sandra K. Klein: Austrian Capital 
Theory and the Link Between Entrepreneurship and the Theory of the Firm

2005-1: Nicolai J. Foss: The Knowledge Governance Approach

2005-2: Torben J. Andersen: Capital Structure, Environmental Dynamism, Innovation Strategy, and Strategic Risk Management

2005-3: Torben J. Andersen: A Strategic Risk Management Framework for Multinational Enterprise

2005-4: Peter Holdt Christensen: Facilitating Knowledge Sharing: A Conceptual Framework

2005-5 Kirsten Foss \& Nicolai J. Foss: Hands Off! How Organizational Design Can Make Delegation Credible

2005-6 Marjorie A. Lyles, Torben Pedersen \& Bent Petersen: Closing the Knowledge Gap in Foreign Markets - A Learning Perspective

2005-7 Christian Geisler Asmussen, Torben Pedersen \& Bent Petersen: How do we Capture "Global Specialization" when Measuring Firms' Degree of internationalization?

2005-8 Kirsten Foss \& Nicolai J. Foss: Simon on Problem-Solving: Implications for New Organizational Forms

2005-9 Birgitte Grøgaard, Carmine Gioia \& Gabriel R.G. Benito: An Empirical Investigation of the Role of Industry Factors in the Internationalization Patterns of Firms

2005-10 Torben J. Andersen: The Performance and Risk Management Implications of Multinationality: An Industry Perspective

2005-11 Nicolai J. Foss: The Scientific Progress in Strategic Management: The case of the Resource-based view

2005-12 Koen H. Heimeriks: Alliance Capability as a Mediator Between Experience and Alliance Performance: An Empirical Investigation Into the Alliance Capability Development Process

2005-13 Koen H. Heimeriks, Geert Duysters \& Wim Vanhaverbeke: Developing Alliance Capabilities: An Empirical Study

2005-14 JC Spender: Management, Rational or Creative? A Knowledge-Based Discussion

\section{6}

2006-1: Nicolai J. Foss \& Peter G. Klein: The Emergence of the Modern Theory of the Firm

2006-2: Teppo Felin \& Nicolai J. Foss: Individuals and Organizations: Thoughts on a Micro-Foundations Project for Strategic Management and Organizational Analysis

2006-3: Volker Mahnke, Torben Pedersen \& Markus Venzin: Does Knowledge Sharing 
Pay? An MNC Subsidiary Perspective on Knowledge Outflows

2006-4: Torben Pedersen: Determining Factors of Subsidiary Development

2006-5 Ibuki Ishikawa: The Source of Competitive Advantage and Entrepreneurial Judgment in the RBV: Insights from the Austrian School Perspective

2006-6 Nicolai J. Foss \& Ibuki Ishikawa: Towards a Dynamic Resource-Based View: Insights from Austrian Capital and Entrepreneurship Theory

2006-7 Kirsten Foss \& Nicolai J. Foss: Entrepreneurship, Transaction Costs, and Resource Attributes

2006-8 Kirsten Foss, Nicolai J. Foss \& Peter G. Klein: Original and Derived Judgement: An Entrepreneurial Theory of Economic Organization

2006-9 Mia Reinholt: No More Polarization, Please! Towards a More Nuanced Perspective on Motivation in Organizations

2006-10 Angelika Lindstrand, Sara Melen \& Emilia Rovira: Turning social capital into business? A study of Swedish biotech firms' international expansion

2006-11 Christian Geisler Asmussen, Torben Pedersen \& Charles Dhanaraj: Evolution of Subsidiary Competences: Extending the Diamond Network Model

2006-12 John Holt, William R. Purcell, Sidney J. Gray \& Torben Pedersen: Decision Factors Influencing MNEs Regional Headquarters Location Selection Strategies

2006-13 Peter Maskell, Torben Pedersen, Bent Petersen \& Jens Dick-Nielsen: Learning Paths to Offshore Outsourcing - From Cost Reduction to Knowledge Seeking

2006-14 Christian Geisler Asmussen: Local, Regional or Global? Quantifying MNC Geographic Scope

2006-15 Christian Bjørnskov \& Nicolai J. Foss: Economic Freedom and Entrepreneurial Activity: Some Cross-Country Evidence

2006-16 Nicolai J. Foss \& Giampaolo Garzarelli: Institutions as Knowledge Capital: Ludwig M. Lachmann's Interpretative Institutionalism

2006-17 Koen H. Heimriks \& Jeffrey J. Reuer: How to Build Alliance Capabilities

2006-18 Nicolai J. Foss, Peter G. Klein, Yasemin Y. Kor \& Joseph T. Mahoney: Entrepreneurship, Subjectivism, and the Resource - Based View: Towards a New Synthesis

2006-19 Steven Globerman \& Bo B. Nielsen: Equity Versus Non-Equity International Strategic Alliances: The Role of Host Country Governance

\section{7}

2007-1 Peter Abell, Teppo Felin \& Nicolai J. Foss: Building Micro-Foundations for the Routines, Capabilities, and Performance Links 
2007-2 Michael W. Hansen, Torben Pedersen \& Bent Petersen: MNC Strategies and Linkage Effects in Developing Countries

2007-3 Niron Hashai, Christian G. Asmussen, Gabriel R.G. Benito \& Bent Petersen: Predicting the Diversity of Foreign Entry Modes

2007-4 Peter D. Ørberg Jensen \& Torben Pedersen: Whether and What to Offshore?

2007-5 Ram Mudambi \& Torben Pedersen: Agency Theory and Resource Dependency Theory: Complementary Explanations for Subsidiary Power in Multinational Corporations

2007-6 Nicolai J. Foss: Strategic Belief Management

2007-7 Nicolai J. Foss: Theory of Science Perspectives on Strategic Management Research: Debates and a Novel View

2007-8 Dana B. Minbaeva: HRM Practices and Knowledge Transfer in MNCs

2007-9 Nicolai J. Foss: Knowledge Governance in a Dynamic Global Context: The Center for Strategic Management and Globalization at the Copenhagen Business School

2007-10 Paola Gritti \& Nicolai J. Foss: Customer Satisfaction and Competencies: An Econometric Study of an Italian Bank

2007-11 Nicolai J. Foss \& Peter G. Klein: Organizational Governance

2007-12 Torben Juul Andersen \& Bo Bernhard Nielsen: The Effective Ambidextrous Organization: A Model of Integrative Strategy Making Processes.

\section{8}

2008-1 Kirsten Foss \& Nicolai J. Foss: Managerial Authority When Knowledge is Distributed: A Knowledge Governance Perspective

2008-2 Nicolai J. Foss: Human Capital and Transaction Cost Economics.

2008-3 Nicolai J. Foss \& Peter G. Klein: Entrepreneurship and Heterogeneous Capital.

2008-4 Nicolai J. Foss \& Peter G. Klein: The Need for an Entrepreneurial Theory of the Firm.

2008-5 Nicolai J. Foss \& Peter G. Klein: Entrepreneurship: From Opportunity Discovery to Judgment.

2008-6 Mie Harder: How do Rewards and Management Styles Influence the Motivation to Share Knowledge?

2008-7 Bent Petersen, Lawrence S. Welch \& Gabriel R.G. Benito: Managing the Internalisation Process - A Theoretical Perspective.

2008-8 Torben Juul Andersen: Multinational Performance and Risk Management Effects: Capital Structure Contingencies. 
2008-9 Bo Bernard Nielsen: Strategic Fit and the Role of Contractual and Procedural Governance in Alliances: A Dynamic Perspective.

2008-10 Line Gry Knudsen \& Bo Bernhard Nielsen: Collaborative Capability in R\&D Alliances: Exploring the Link between Organizational and Individual level Factors.

2008-11 Torben Juul Andersen \& Mahesh P. Joshi: Strategic Orientations of Internationalizing Firms: A Comparative Analysis of Firms Operating in Technology Intensive and Common Goods Industries.

2008-12 Dana Minbaeva: HRM Practices Affecting Extrinsic and Intrinsic Motivation of Knowledge Receivers and their Effect on Intra-MNC Knowledge Transfer.

2008-13 Steen E. Navrbjerg \& Dana Minbaeva: HRM and IR in Multinational Corporations: Uneasy Bedfellows?

2008-14 Kirsten Foss \& Nicolai J. Foss: Hayekian Knowledge Problems in Organizational Theory.

2008-15 Torben Juul Andersen: Multinational Performance Relationships and Industry Context.

2008-16 Larissa Rabbiosi: The Impact of Subsidiary Autonomy on MNE Knowledge Transfer: Resolving the Debate.

2008-17 Line Gry Knudsen \& Bo Bernhard Nielsen: Organizational and Individual Level Antecedents of Procedural Governance in Knowledge Sharing Alliances.

2008-18 Kirsten Foss \& Nicolai J. Foss: Understanding Opportunity Discovery and Sustainable Advantage: The Role of Transaction Costs and Property Rights.

2008-19 Teppo Felin \& Nicolai J. Foss: Social Reality, The Boundaries of Self-fulfilling Prophecy, and Economics.

2008-20 Yves Dos, Nicolai J. Foss \& José Santos: A Knowledge System Approach to the Multinational Company: Conceptual Grounding and Implications for Research

2008-21 Sabina Nielsen \& Bo Bernhard Nielsen: Why do Firms Employ foreigners on Their Top Management Teams? A Multi-Level Exploration of Individual and Firm Level Antecedents

2008-22 Nicolai J. Foss: Review of Anders Christian Hansen's “Uden for hovedstrømmen - Alternative strømninger i økonomisk teori"

2008-23 Nicolai J. Foss: Knowledge, Economic Organization, and Property Rights

2008-24 Sjoerd Beugelsdijk, Torben Pedersen \& Bent Petersen: Is There a Trend Towards Global Value Chain Specialization? - An Examination of Cross Border Sales of US Foreign Affiliates 
2008-25 Vikas Kumar, Torben Pedersen \& Alessandro Zattoni: The performance of business group firms during institutional transition: A longtitudinal study of Indian firms

2008-26 Sabina Nielsen \& Bo B. Nielsen: The effects of TMT and Board Nationality Diversity and Compensation on Firm Performance

2008-27 Bo B. Nielsen \& Sabina Nielsen: International Diversification Strategy and Firm Performance: A Multi-Level Analysis of Firm and Home Country Effects

\section{9}

2009-1 Nicolai J. Foss: Alternative Research Strategies in the Knowledge Movement: From Macro Bias to Micro-Foundations and Multi-Level Explanation

2009-2 Nicolai J. Foss \& Peter G. Klein: Entrepreneurial Alertness and Opportunity Discovery: Origins, Attributes, Critique

2009-3 Nicolai J. Foss \& Dana B. Minbaeva: Governing Knowledge: The Strategic Human Resource Management Dimension

2009-4 Nils Stieglitz \& Nicolai J. Foss: Opportunities and New Business Models: Transaction Cost and Property Rights Perspectives on Entrepreneurships

2009-5 Torben Pedersen: Vestas Wind Systems A/S: Exploiting Global R\&D Synergies

2009-6 Rajshree Agarwal, Jay B. Barney, Nicolai J. Foss \& Peter G. Klein: Heterogeneous Resources and the Financial Crisis: Implications of Strategic Management Theory

2009-7 Jasper J. Hotho: A Measure of Comparative Institutional Distance

2009-8 Bo B. Nielsen \& Sabina Nielsen: The Impact of Top Management Team Nationality Diversity and International Experience on Foreign Entry Mode

2009-9 Teppo Felin \& Nicolai Juul Foss: Experience and Repetition as Antecedents of Organizational Routines and Capabilities: A Critique of Behaviorist and Empiricist Approaches

2009-10 Henk W. Volberda, Nicolai J. Foss \& Marjorie E. Lyles: Absorbing the Concept of Absorptive Capacity: How To Realize Its Potential in the Organization Field 